\title{
Nonlinear responses of consumption to wealth, income, and interest rate shocks
}

\author{
Yener Coskun $^{1}$ (D) $\cdot$ Nicholas Apergis $^{2}$ (D) Esra Alp Coskun ${ }^{3}$ (D)
}

Received: 16 June 2020 / Accepted: 14 November 2021 / Published online: 8 January 2022

(C) The Author(s), under exclusive licence to Springer-Verlag GmbH Germany, part of Springer Nature 2021, corrected publication 2022

\begin{abstract}
Nonlinear adjustments of consumption to housing prices, stock prices, income, and interest rates were investigated by employing panel data from 25 countries, spanning the period 2000 to 2016 . This is the first study which STAR family models and nonlinear impulse response functions based on the local projections employed alternatively. We present three main pieces of evidence: (1) housing prices, stock prices, interest rates, and income exposures of consumption show time-varying and asymmetric behaviours across all countries, (2) housing wealth effects show stronger persistency and are generally larger than financial wealth effects in most of the countries, and (3) time-varying housing and financial wealth effects are high (low) during expansionary (recessionary) periods across all countries. We suggest to consider both monetary and fiscal policies, as well as the asymmetric and time-varying nature of house prices, stock prices, income, and interest rates on the top of any potential impact of the level of transition in these variables.
\end{abstract}

Keywords Consumption asymmetry · Wealth effect heterogeneity · Behavioural wealth effect $\cdot$ STAR family models $\cdot$ Nonlinear impulse response functions

JEL Classification E21 - E52 - D31 - R31

\footnotetext{
$凶 \quad$ Yener Coskun ycoskun@spk.gov.tr

Nicholas Apergis napergis@unipi.gr

Esra Alp Coskun esraalpcoskun@gmail.com

1 Capital Market Board of Turkey, TED University, Mustafa Kemal Mah, Dumlupinar Blv. 8.Km, No: 156, 06530 Çankaya, Ankara, Turkey

2 University of Piraeus, Piraeus, Greece

3 Middle East Technical University, Ankara, Turkey
} 


\section{Introduction}

The permanent income theory (Friedman 1957) and the life cycle model (Ando and Modigliani 1963), respectively, suggest that consumption is determined by future income expectations while being smoothed by the life cycle effect. Consumers' response to income and wealth shocks results in variations in consumption (Boone et al. 2002). Specifically, in the last two decades, the world economy experienced a large-scale cyclicality due to unending bubble-post-bubble environment, including the dot-com bubble (2000-2003), the global financial crisis (GFC) (2007-2010), and possibly the Covid-19 period. It seems that households do not change of their consumption habits immediately in these episodes. However, several macroeconomic and psychological factors may affect consumption in this highly volatile economic environment. Therefore, intuitively, it is not surprising to expect some cyclical and nonlinear (i.e. asymmetric and/or time varying) behaviours in consumption and its components (Elliot 1980). However, the empirical literature reveals that wealth effects are mostly analysed through linear models with some rare exceptions (i.e. see Simo-Kengne et al. 2013; Jawadi and Sousa 2014; Hviid and Kuchler 2017; Berger et al. 2017; Jawadi et al. 2017). Moreover, despite a better articulation of the presence of wealth effect, the time-varying and asymmetric relationship that may exist between house prices, stock prices, income, interest rates, and consumption has not received much scholarly attention. From a policy-making perspective, ignoring possible influences of state dependency and asymmetry in linear modelling may probably prepare a ground for possible mistakes in consumption-related economic policies (Tsai et al. 2011; Jawadi and Leoni 2012).

In addition to this critical modelling gap, the emerging asymmetric and time-varying wealth effect literature mainly focuses on house and stock price asymmetries and the impact of the remaining consumption-related variables has been generally less investigated. However, rising income and wealth inequalities, declining real interest rates (Del Negro et al. 2019), and injecting helicopter drops all over the world during postGFC and Covid-19 periods imply that the shocks on marginal propensity to consume out of income and interest rate may also play an important role in the transmission of economic policies (i.e. see Donihue and Avramenko 2007; MacDonald et al. 2011; Simo-Kengne et al. 2013; Bunn et al. 2018). This observation suggests that a more holistic approach with an expanded variable set and sample in wealth effects studies may improve our understanding.

Motivated by the above-mentioned concerns, this paper aims to address certain gaps in the empirical literature. We examine nonlinear adjustments of consumption to housing wealth, financial wealth, interest rates, and income for the panel data of $25-$ mostly OECD_countries during the period of 2000 and 2016 by employing logistic smooth transition autoregressive (LSTAR), exponential STAR (ESTAR), and smooth transition autoregressive with exogenous transition (STARX) modelling approaches and nonlinear impulse response functions based on local projections.

This study differs from previous empirical studies in three main respects. First, to the best of our knowledge, there has been no investigation of the impact of housing wealth, financial wealth, interest rates, and income on consumption that allows the analysis of state dependency and asymmetry during expansionary and recessive periods for 
25 countries in nonlinear modelling through simultaneously employing STAR family models and impulse response functions. In the light of modelling and evidence sets, first, we argue that a nonlinear modelling framework better explains the impact of a wide range of heterogeneity in housing and financial wealth effects. Second, we provide evidence that on the top of income and interest rates, housing and stock prices exposures to consumption generally show a persistent, asymmetric, and time-varying behaviour. For the latter nonlinear effect, we also generally report semi-strong or weak transitions from one regime to another. This evidence, with extensive country-level evidence set, gives a generalization opportunity for the time-varying and asymmetric wealth effect and consumption literature. Third, we attempt to classify panel countries based on various country-specific evidence and their financial and housing market characteristics. This classification helps to develop a more sophisticated policy tool for policymakers aiming to adopt a cyclical housing and financial wealth effect, income, and interest rates policies during different market regimes.

The remainder of the paper is organized as follows. Section 2 reviews the literature. Section 3 outlines the data and the modelling strategy. Empirical results are presented in Sect. 4, while discussion and policy suggestions are offered in Sect. 5. Finally, Sect. 6 concludes. Additionally, Appendix 1, Appendix 2, and Appendix 3, respectively, present the total coefficients, classification of countries based on their transition speeds, and selected economic and financial characteristics.

\section{Literature review}

\subsection{Asymmetric responses of consumption to housing and financial wealth shocks}

The large body of findings reveals that housing wealth is generally found to have a stronger effect than the financial wealth on consumption (i.e. see Benjamin et al. 2004; Sousa 2005; Bostic et al. 2009; Case et al. 2013). Despite some counter-evidence (i.e. see Sousa 2005; Donihue and Avramenko 2007), empirical studies also generally suggest that the housing and financial wealth effects may show cyclical and asymmetric behaviour across countries, as well as across different market regimes (i.e. see Romer 1990; Lettau and Ludvigson 2004).

The asymmetric behaviour of consumption would be related to several factors such as concave consumption function produced by income uncertainty and risk aversion (Carroll and Kimball 1996), loss aversion (Shirvani and Wilbratte 2000), imperfect capital markets (Patterson 1993), varying perceptions of liquidity (Shefrin and Thaler 1988), and the combination of liquidity constrains and business cycles (i.e. see Apergis and Miller 2006). Unequal or asymmetric responses of consumption to changes in prices may have different features in the housing market due to its different nature vis-à-vis non-financial assets. For example, Case et al. $(2005 ; 2011)$ indicate that reductions in housing prices and wealth may not lead to significant declines (or may result in only marginal decline) in households' consumption. Moreover, the literature reveals that perceived less volatility (Catte et al. 2004), rather evenly distribution of wealth (Catte et al. 2004; Mishkin 2007), downward stickiness of prices (Case and Quigley 2008; Tsai et al. 2011), and consumption insurance function (Bostic 
et al. 2009) in housing may result in different consumption and nonlinear adjustment patterns in housing wealth.

The magnitude of housing and financial wealth effects shows variations across countries depending on various features. For example, the empirical results suggest that market-based Anglo-Saxon economies may have strong wealth effects (i.e. Slacalek 2009; Albacete and Lindner 2017). Despite complexities, the emerging literature suggests that the level of market completeness and market characteristics may also play roles in the wealth effect variations (i.e. see Li and Yao 2007). From the housing market perspective, depending also on the effect of leverage, house price appreciation may play a critical role in strengthening the housing wealth effect. However, as observed during and afterwards the subprime mortgage crisis period, deleveraging may also result in significant drawbacks.

On top of certain rational dynamics, psychological factors may also play a significant role in consumption decisions. As the historical perspective for the subject, the modern consumption theory begins with Keynes' (1936) analysis on the psychological foundation of the consumption behaviour in his General Theory (Palley 2010). D'Orlando and Sanfilippo (2010) discuss that major psychological motivations in individuals' consumption decisions are a preference for procrastination, cognitive scarcity, myopia and prodigality, mental budgeting, and debt aversion. From the specific behavioural perspective, the psychology of framing may play a role in different responses to changes in financial or housing wealth (Shefrin and Thaler 1988; Thaler 1990). Thaler (1994) argues that wealth coming in the form of current income is almost entirely consumed, but wealth coming in the form of an increase in home equity or pension assets has little or no effect on consumption. The life cycle theory can be enriched by assuming that households have a set of 'mental accounts' with varying marginal propensities to consume. Poterba et al. (1995) suggest that stock price changes may affect consumption through the channels of wealth and the signalling effects (Leibenstein 1950). The well-known signalling phenomena are the 'keeping up with the Joneses effect' (Gali 1994), the "bandwagon effect" (Nadeau et al. 1993), the 'Snob effect', and the 'Veblen effect' (Veblen 1899; Leibenstein 1950). However, the behavioural wealth effect literature reveals little knowledge on this effect. As rare examples, Starr-McCluer (2002) and Groenewold (2003) find conflicting evidence visa-vis the conclusions reached by Poterba et al., (1995) who assert that wealth effects on consumption are likely to be small relative to signalling effects (Groenewold 2003). Schooley and Worden (2008) utilize survey data to examine the wealth effect within the context of the behavioural life cycle model of savings. Their results indicate that the likelihood of households spending is much more when their assets increase in value decreases with the portion of assets held in home equity.

\subsection{Asymmetric responses of consumption to income and interest rate shocks}

The asymmetries in consumption responses to positive and negative income and interest rate shocks have significant implications to economic policies. The literature generally reveals that income and interest rate shocks may have time-varying and asymmetric impacts on consumption with different country-level patterns. For 
example, Jawadi and Léoni (2012) find robust evidence of persistence, nonlinearity and cyclicity in the relationship between consumption and income. Bunn et al. (2018), based on UK survey data, highlight that MPCs out of negative income shocks are estimated to be much larger than those for positive shocks. Based on a survey data, Christelis et al. (2019) detect significant asymmetries of the MPC in response to positive and negative income shocks in the Netherlands.

On the other hand, there is a vast literature investigating the relationship between interest rates and consumption. The literature reveals that this linkage would be complex and uncertain (Keynes 1936), time dependent (Hansen 1996), and irrational (Campbell and Mankiw 1989). The evidence is mixed for the direction between two variables (i.e. for the inverse relation: Wright 1967; Boskin 1978; Mishkin 1976; Gylfason 1981, i.e. for the positive relation: Springer 1975) and also for the impact of interest rates on demand, the activity level, and consumption growth (i.e. Ludvigson et al. 2002). We have a special focus on the studies employing (real) interest rates in a declining and rising market environments due to our similar data structure. In this respect, Gourinchas and Rey (2018) argue that real interest rates do not systematically co-move with real consumption growth. Del Negro et al. (2019) document that both real interest rates and growth rates of per capita consumption decline globally due to possibly demographic shifts. Moreover, the magnitude of the relation between interest rates and consumption is also a subject of debate in the empirical studies. Previous literature generally suggests weak impact of interest rates on consumption (i.e. see Siokis 2005; Kapoor and Ravi 2009; MacDonald et al. 2011; Hviid and Kuchler 2017).

\subsection{Nonlinear modelling, STAR family models, and nonlinear impulse response functions}

The recent studies suggest that the linear approaches may not be appropriate if adjustments from disequilibrium are asymmetric for housing and stock markets (Tsai et al. 2011). In line with several findings in the empirical literature, our study also argues that nonlinear models may better explain the regime-dependent time variations and asymmetries in house prices, stock prices, income, and interest rates (also see Jawadi and Leoni 2012; Katrakilidis and Trachanas 2012). However, wealth effects on consumption are mostly analysed through linear models in the literature. Just few papers make use of nonlinear models. For example, by employing SETAR cointegration models and arguing that these models can better analyse the presence of asymmetric effects in the relationship between consumption and some of its determinants, Mignon and Dufrénot (2004) illustrate that consumption is described by two regimes that signify the presence of a heterogeneous behaviour. Teräsvirta and Anderson (1992) indicate that LSTAR and ESTAR models can widely describe different kinds of dynamic economic behaviours, which make the STAR family models as a promising tool for modelling nonlinearities in business cycles. As it is stated in González-Rivera (1998), a sharp transition function indicates two regimes, high versus low volatility (Markovswitching), whereas a smoother transition function allows for intermediate regimes that are continuous and may exhibit different degrees of smoothness. Hence, among 
these regime-switching models, the STAR family models best fit in our case, since consumption may possibly respond to changes in income, interest rates, house prices, and stock prices in a smooth way instead of a sharp transition.

On the other hand, a few studies apply impulse response analysis in order to examine the effects of shocks on consumption (see Lettau et al. 2002; Berger and Vavra 2015; Alp and Seven 2019). To the best of our knowledge, our study is the first one that applies nonlinear impulse response functions based on local projections (Jorda 2005) in order to analyse the asymmetric responses of household consumption to the shocks from housing wealth, stock wealth, income, and interest rates in different housing wealth regimes for a panel of countries. By employing this pioneering framework, we aim to distinguish the responses of consumption to the shocks in low- and high-housing wealth regimes. The results of STAR models illustrate the time-varying relationship between consumption and its determinants in both recession and expansion regimes that occur based on GDP (income) shocks. To examine asymmetries by employing nonlinear impulse response functions, we use house prices (housing wealth) for the regime-switching variable as the second most effective determinant of consumption in our modelling framework (Case et al. 2001; Dvornak and Kohler 2003; Benjamin et al. 2004; Iacoviello 2004, among others).

Overall, nonlinear (i.e. asymmetric and time-varying) responses of consumption to housing wealth, financial wealth, income, and interest rate shocks are emerging literature comparing to the prior rich literature of the linear wealth effect. However, the literature review reveals that heterogeneities in the consumption responses to the house price, stock price, income, and interest rate shocks have not been tested yet by simultaneously using STAR family models and nonlinear impulse response functions. Specifically, the latter modelling had no application previously. Our study is the first one of its kind.

\section{Data and modelling strategy}

\subsection{Data}

The empirical literature on the consumption-wealth effect channel suggests that there is a trade-off between developing a comprehensive independent variable set and data availability, specifically in a panel analysis framework. This paper involves a substantial effort to construct a wide range of a variable set for an unbalanced panel data from 25 countries, which are mostly OECD members, over the 2000Q1-2016Q4 period. The period and sample preference are shaped by data availability. The country sample includes Australia, Austria, Belgium, Canada, Denmark, Finland, France, Germany, Greece, Ireland, Israel, Italy, Japan, Korea, Netherlands, New Zealand, Norway, Portugal, Russia, South Africa, Spain, Sweden, Switzerland, the UK, and the USA.

In line with the literature (i.e. Ludvigson et al. 2002; Siokis 2005; MacDonald et al. 2011), we employ per capita household's final consumption as the dependent variable and income, housing wealth, financial wealth, and also interest rates as the independent variables. All series are deflated by the consumer price index provided by the IFS (International Financial Statistics) database-except interest rate-and expressed in 
their natural logarithms. We used the Fisher equation in order to calculate the real interest rates. The Fisher equation states that the nominal interest $(i)$ rate equals the real interest (ir) rate plus the expected rate of inflation $(\pi e)$ (Fisher 1930).

$$
i=i r+\pi e
$$

Households' final consumption ${ }^{1}$ and $\mathrm{GDP}^{2}$ (as a proxy of income) are obtained from the same database, as well. Both data sets are seasonally adjusted and involve nominal domestic currency values expressed in US dollars. In the construction of income and consumption, we use exchange rates ${ }^{3}$ and population ${ }^{4}$ data provided by both the IFS and the World Bank databases, respectively. The population series is interpolated from annual data. Stock and house price indexes are used as proxy variables for financial wealth and housing wealth, respectively. Obtained from the OECD national accounts database, ${ }^{5}$ real house prices are defined as the ratio of seasonally adjusted nominal house prices to the seasonally adjusted consumers' expenditure deflator in each country. Sourced from the OECD (Main Economic Indicators: Finance) database, ${ }^{6}$ stock price indices involve closing daily values of common stocks. For interest rates, the analysis employs 10-year government bond interest rates for all countries, except Israel, where it uses T-Bill interest rates. All data are retrieved from the IFS database, except Norway data which are provided by the Norges Bank. ${ }^{7}$

In the light of the discussions in Catte et al. (2004), Li and Yao (2007), Slacelek (2009), Peltonen et al. (2012), among others, as the additional information set to better understand the evidence, we attempt to classify sample countries in Table 8 (in Appendix 3) based on the following the criteria: size of the economy (small vs. big), level of economic development (advanced vs. emerging), level of financial development (advanced vs. high), the role of banking and stock markets (bank vs. market based), income level (high vs. upper middle income), housing ownership ratio, ownership trends, and economic memberships (such as EU member, OECD member or an Anglo-Saxon country).

\subsection{Modelling strategy: nonlinear adjustments to wealth effects}

In order to examine nonlinear adjustments of consumption, the analysis considers the univariate Smooth Transition Autoregressive model (STAR), developed by Luukkonen et al. (1988). For a $p$ order, the STAR $(p)$ model yields:

\footnotetext{
1 Available at: http://data.imf.org/regular.aspx?key=61545864 (accessed on: 10.6.2019).

2 Available at: http://data.imf.org/regular.aspx?key=61545864 (accessed on: 10.6.2019).

3 Available at: http://data.imf.org/regular.aspx?key=61545862 (accessed on: 10.6.2019).

4 Available at: https://databank.worldbank.org/data/reports.aspx?source=global-financial-development\& preview=on\# (accessed on: 10.6.2019). Total population is based on the de facto definition of population, which counts all residents regardless of legal status or citizenship.

5 Available at: https://stats.oecd.org/Index.aspx?DataSetCode=HOUSE_PRICES\# (accessed on: 10.6.2019).

6 Available at: https://data.oecd.org/price/share-prices.htm\#indicator-chart (accessed on: 10.6.2019).

7 Available at: http://data.imf.org/regular.aspx?key=61545867; https://www.norges-bank.no/en/Statistics/ Interest-rates/Government-bonds-monthly/ (accessed on: 10.6.2019).
} 


$$
c_{t}=a_{0}+a_{1} x_{t}+\left(b_{0}+b_{1} x_{t}\right) \times F\left\{\gamma\left(y_{t-d}-c\right)\right\}+\varepsilon_{t}
$$

where $c_{t}$ is consumption, $x_{t}$ includes a number of control variables that affect consumption, such as income, interest rates, stock prices, and housing prices, while $F\left\{\gamma\left(y_{t-d}-c\right)\right\}$ is the transition function from one regime to another with $0 \leq F \leq 1$. This function allows for a smooth transition between the extreme regimes and depends on three parameters: $y_{t-d}$ is the transition variable, where $\mathrm{d}$ is the delay parameter $(1 \leq d \leq p)$; $\gamma$ is the speed of transition between two extreme regimes; and $\mathrm{c}$ is the half-way point between the two regimes. $\varepsilon_{t}$ are independently, $N\left(0, \sigma_{\varepsilon}{ }^{2}\right)$. Luukkonen et al. (1988), Teräsvirta and Anderson (1992) and Teräsvirta (1994) define two types of STAR models depending on the nature of the transition function: Logistic STAR (LSTAR) and Exponential STAR (ESTAR) models. The transition function can be a logistic form:

$$
F\left(S_{t-d}\right)=\left\{1+\exp \left[-\gamma\left(S_{t-d}-c\right)\right]\right\}^{-1}, \gamma>0
$$

where $\gamma$ is the smooth parameter, measuring the transition speed from one regime to the other, and $c$ indicates the threshold. When $\gamma$ is greater than 0 , the degree of autoregressive decay depends on the transition variable, $S_{t-d}$; when $S_{t-d}$ is far above the threshold, the value of the transition function approaches to one; when $S_{t-d}$ is far below the threshold, the value of the transition function approaches to zero. Hence, the LSTAR model characterizes asymmetric processes of consumption cycles. The transition function can be also described as an exponential form:

$$
F\left(S_{t-d}\right)=\left\{1+\exp \left[-\gamma\left(S_{t-d}-c\right)^{2}\right]\right\}^{-1}, \gamma>0
$$

When $\gamma$ is between 0 and $\infty$, the degree of autoregressive decay depends on the transition variable, $S_{t-d}$; as $S_{t-d}$ is close to the threshold, the value of the transition function approaches to zero; as $S_{t-d}$ moves farther away from the threshold, the value of the transition function is one. The ESTAR model suggests similar dynamics for low and high values of the transition variable, but different dynamics for the mid-range of the transition variable. Given, however, that we need to consider a number of other control variables that affect consumption, the empirical analysis makes use of a variant of the LSTAR or ESTAR modelling procedure, that of the Smooth Transition Autoregressive with Exogenous Transition (STARX) model, first applied by McMillan (2001). This version of nonlinear models employs as explanatory variables lagged control variables, rather than lagged dependent variables, to reveal the nonlinear smooth switching process of the dependent variable, which in our case is consumption.

The existing literature does not address wealth effect asymmetries through nonlinear impulse response functions based on the local projections (LP). To analyse the response of consumption to income, housing wealth, financial wealth and interest rates, we estimate impulse response functions using the LP method suggested by Jorda (2005) and applied in a different context by Barnichon and Brownlees (2019) and Adämmer (2019), among others. The LP model has many advantages over traditional structural vector autoregressive (SVAR) approach; for example, (1) LP models are easier to estimate since they rely merely on simple linear regressions, (2) the point or joint-wise 
inference is easily conducted, (3) the LP method is more robust to misspecifications, it does not suffer from the curse of dimensionality inherent to VARs, and (4) it is easier to accommodate for nonlinearities (Jorda 2005; Barnichon ve Brownlees 2019; Adämmer 2019).

We followed Auerbach and Gorodnichenko (2013) in order to estimate Eq. (4), and we used the Hodrick-Prescott filter to decompose the series. ${ }^{8}$

$$
\begin{gathered}
y_{t+h}=\alpha^{h}+B_{1, R_{1}}^{h}\left(y_{t-1} \cdot\left(1-F\left(z_{t-1}\right)\right)+\cdots+B_{p, R_{1}}^{h}\left(y_{t-p} \cdot\left(1-F\left(z_{t-1}\right)\right)\right.\right. \\
+B_{1, R_{2}}^{h}\left(y_{t-1} \cdot F\left(z_{t-1}\right)+\cdots+B_{p, R_{2}}^{h}\left(y_{t-1} \cdot F\left(z_{t-1}\right)+u_{t+h^{\prime}}^{h}\right.\right. \\
0, \ldots, H-1
\end{gathered}
$$

In order to compute the LP approach for the estimation of impulse responses, the analysis uses the 'lpirfs: Local Projections Impulse Response Functions package from the R software (Adämmer 2019). The data are split into two regimes by considering the housing wealth as the switching variable due to greater, persistent, and stable impacts of the housing market on consumption as documented in the literature (i.e. Catte et al. 2004; Case et al. 2005; 2011; Mishkin 2007). In this respect, one regime corresponds to a low-housing wealth regime, while the other regime represents the high-housing wealth regime. In Eq. (4), $z_{t}$ corresponds to housing wealth and an increase in $z_{t}$ (housing wealth) leads to a decrease in $F\left(z_{t}\right)$. If the values of $F\left(z_{t}\right)$ are close to zero, this implies a high-housing wealth regime (expansion regime), and vice versa.

\section{Model results}

\subsection{Linearity tests}

The first step of the method determines the optimal lag based on the Ljung and Box (1978) test of residual autocorrelation, along with the Akaike (1974) and Schwarz (1978) information criteria. Next, testing for linearity against STAR models nonlinearity, Luukkonen et al., (1988) suggest a test to get a linear approximation of the transition function using Taylor approximation. The null hypothesis is linearity. Once linearity is rejected, we determine the delay parameter $d$ using the Teräsvirta (1994) criteria: firstly, the lag $p$ of the autoregressive model, varying $d$, and then choosing the value that minimizes the probability of the linearity test. If the linearity is rejected for many values of $d$, then we choose the one for which the linearity is strongly rejected, where Pr is the probability of the Fisher statistic associated with the null hypothesis of linearity. The approach estimates the following auxiliary equation:

\footnotetext{
8 Adämmer (2019) points out that the parameter should be determined by the user. $F\left(z_{t}\right)=\frac{e^{(-\gamma z t)}}{\left(1+e^{\left(-\gamma z_{t}\right)}\right)^{\prime}}$ In the above equation, the value of $\gamma=1.5$ is determined by Auerbach and Gorodnichenko (2013). The value of smoothing parameter for quarterly data is $\lambda=1600$ suggested by Hodrick and Prescott $(1980 ; 1997)$ and tested by Ravn and Uhlig (2002) and applied by many researchers (i.e. Kydland and Prescott, 1990; Backus and Kehoe, 1992; Harvey and Trimbur, 2008; De Jong and Sakarya, 2016; Hamilton, 2018;Adämmer, 2019).
} 


$$
c_{t}=a_{0}+a_{1} x_{t}+\sum_{j=1}^{P} a_{2 j} x_{t-j} s_{t-d}+\sum_{j=1}^{p} a_{3 j} x_{t-j} s_{t-d}^{2}+\sum_{j=1}^{p} a_{4 j} x_{t-j} s_{t-d}^{3}+u_{t}
$$

The null hypothesis for linearity test is $\alpha_{2 j}=\alpha_{3 j}=\alpha_{4 j}=0, j=1, \ldots, p$. We chose $\mathrm{d}$ when the linearity is rejected with the smallest test statistic of $\mathrm{p}$-value. The results, along with the used lags, are reported in Table 1 . They clearly illustrate the rejection of linearity across all countries in our sample at the 5\% significance level.

In addition, given that this standard linearity test might reject the null hypothesis of linearity, we should also double check whether this linearity is really rejected because of nonlinearity and NOT autocorrelation, or outliers, or heteroscedasticity. Therefore,

Table 1 Linearity test results

\begin{tabular}{|c|c|c|c|}
\hline Country & Lags & $d$ & $p$-value \\
\hline Australia & 2 & 2 & {$[0.02]$} \\
\hline Austria & 2 & 2 & {$[0.02]$} \\
\hline Belgium & 1 & 2 & {$[0.03]$} \\
\hline Canada & 2 & 2 & {$[0.02]$} \\
\hline Denmark & 1 & 1 & {$[0.05]$} \\
\hline Finland & 2 & 2 & {$[0.03]$} \\
\hline France & 1 & 1 & {$[0.04]$} \\
\hline Germany & 1 & 1 & {$[0.05]$} \\
\hline Greece & 2 & 2 & {$[0.02]$} \\
\hline Ireland & 1 & 2 & {$[0.03]$} \\
\hline Israel & 2 & 2 & {$[0.03]$} \\
\hline Italy & 2 & 1 & {$[0.02]$} \\
\hline Japan & 1 & 2 & {$[0.03]$} \\
\hline Korea & 1 & 1 & {$[0.02]$} \\
\hline Netherlands & 2 & 1 & {$[0.04]$} \\
\hline New Zealand & 1 & 2 & {$[0.05]$} \\
\hline Norway & 2 & 2 & {$[0.03]$} \\
\hline Portugal & 1 & 2 & {$[0.05]$} \\
\hline Russia & 2 & 2 & {$[0.04]$} \\
\hline South Africa & 2 & 2 & {$[0.03]$} \\
\hline Spain & 1 & 1 & {$[0.05]$} \\
\hline Sweden & 2 & 2 & {$[0.05]$} \\
\hline Switzerland & 1 & 1 & {$[0.04]$} \\
\hline UK & 2 & 1 & {$[0.04]$} \\
\hline USA & 2 & 2 & {$[0.05]$} \\
\hline
\end{tabular}

The chosen delay $(d)$ is that for which the $p$-value $(F)$ is minimal 
we also need to apply robust nonlinearity tests. More specifically, for robustness purposes, the analysis also uses the BDS test (Brock et al. 1987), developed within the chaos theory, which is a very popular test for nonlinearity. It is a nonparametric test, originally designed to test for independence and identical distribution (iid), but shown to also have power against a large gamma of linear and nonlinear alternatives (Brock et al. 1996). Moreover, it can be used as a portmanteau test or miss-specification test when applied to the residuals from a fitted model. Under fairly moderate regularity conditions, the BDS statistic converges in distribution to $N(0,1)$. The BDS test is a nonparametric test with the null hypothesis that the series under study are i.i.d., against an unspecified alternative. The test is based on the concept of correlation integral, a measure of spatial correlation in $n$-dimensional space. Table 2 reports the BDS statistic for embedding dimension ${ }^{8}$. The results strongly reject the null hypothesis of linearity at the 5\% significance level, confirming those obtained in Table 1.

Table 2 BDS linearity test results

\begin{tabular}{lll}
\hline Country & Test & $p$-value \\
\hline Australia & 70.45 & {$[0.03]$} \\
Austria & 65.41 & {$[0.03]$} \\
Belgium & 69.83 & {$[0.03]$} \\
Canada & 72.14 & {$[0.02]$} \\
Denmark & 66.93 & {$[0.03]$} \\
Finland & 62.45 & {$[0.04]$} \\
France & 68.99 & {$[0.03]$} \\
Germany & 67.52 & {$[0.03]$} \\
Greece & 69.82 & {$[0.03]$} \\
Ireland & 71.14 & {$[0.02]$} \\
Israel & 63.44 & {$[0.03]$} \\
Italy & 67.26 & {$[0.03]$} \\
Japan & 71.17 & {$[0.03]$} \\
Korea & 65.19 & {$[0.03]$} \\
Netherlands & 62.84 & {$[0.04]$} \\
New Zealand & 71.09 & {$[0.02]$} \\
Norway & 62.35 & {$[0.04]$} \\
Portugal & 66.18 & {$[0.03]$} \\
Russia & 70.83 & {$[0.02]$} \\
South Africa & 64.52 & {$[0.03]$} \\
Spain & 71.03 & {$[0.02]$} \\
Sweden & 62.58 & {$[0.03]$} \\
Switzerland & 70.14 & {$[0.02]$} \\
UK & 63.29 & {$[0.03]$} \\
USA & 68.22 & {$[0.03]$} \\
\hline & & \\
& &
\end{tabular}

The critical value for the BDS test is 1.96 at $1 \%$ 


\subsection{STAR models}

Next, we choose the appropriate model of STAR family by testing the following restrictions:

$$
\begin{gathered}
H_{0}^{4}=a_{4 j}=0, j=1, \ldots, p \\
H_{0}^{3}=a_{3 j}=0 / a_{4 j}=0, j=1, \ldots, p \\
H_{0}^{2}=a_{2 j}=0 / a_{3 j}=a_{4 j}=0, j=1, \ldots, p
\end{gathered}
$$

If (6) is rejected, we choose the LSTAR model. If (6) is not rejected and (7) is rejected, we choose the ESTAR model. Finally, if (6) and (7) are accepted and (8) is rejected, then we select the LSTAR model. Table 3 reports the results of model specification. Based upon the selection criterion of Akaike (AIC), nonlinear models of all countries are determined. The results indicate that a LSTAR model is employed for the cases of Australia, Austria, Belgium, Canada, France, Germany, Greece, Ireland, Israel, Italy, Japan, Korea, Netherlands, New Zealand, Portugal, Russia, South Africa, Spain, Switzerland, and USA, while in the remaining cases (Denmark, Finland, Norway, and Sweden) an ESTAR model is accepted.

In the final step of the method, we provide the estimates of the modelling approach, through Nonlinear Least Squares. Moreover, to estimate $\gamma$, we divide the estimates by the standard deviation of consumption, $\sigma(c)$, for the LSTAR model, and by the variance of consumption, $\sigma^{2}(\mathrm{c})$, for the ESTAR model (Granger and Teräsvirta 1993; Teräsvirta 1994). Hence, $\gamma$ is scale-free and easier to interpret. The first regime corresponds to an expansion regime, and the second regime defines a recessive regime. The results are reported in Tables 4, 6, and 7, while Fig. 3 provides a summary of the relevant evidence.

In terms of the diagnostics, the Jarque and Béra test statistic clearly shows that the null hypothesis of normality in the residuals cannot be rejected at the $1 \%$ significance level. Similarly, the ARCH test statistic displays that the null hypothesis of homoscedasticity of the residuals at lag 12 cannot be rejected either. Furthermore, the Ljung-Box statistics of order 4 are insignificant, indicating the absence of any autocorrelation in the residuals. Overall, the diagnostics provide statistical support to the good statistical properties of our models.

\subsection{Nonlinear impulse responses of consumption}

To determine the responses of consumption to explanatory variables in both lowand high-housing wealth regimes, we employ nonlinear impulse response functions based on local projections (LP) for a 20-quarter forecasting horizon. This is the first application in the wealth effect and asymmetric consumption empirical literature. We present the visualized evidence in Figs. 1 and 2, and we also categorize the results in Table 5. In all countries, consumption responses to the shocks are asymmetric. In 
Table 3 Specification of the nonlinear model

\begin{tabular}{|c|c|c|c|c|c|}
\hline Country & $H_{0}^{4}$ & $H_{0}^{3}$ & $H_{0}^{2}$ & Model & Akaike (LSTAR-ESTAR) \\
\hline Australia & 0.00 & 0.18 & 0.00 & LSTAR & -2305.64 to 2109.82 \\
\hline Austria & 0.00 & 0.24 & 0.00 & LSTAR & -2445.38 to 2198.58 \\
\hline Belgium & 0.01 & 0.21 & 0.01 & LSTAR & -2.401 .97 to 2.244 .73 \\
\hline Canada & 0.00 & 0.30 & 0.00 & LSTAR & -2386.42 to 2179.36 \\
\hline Denmark & 0.36 & 0.00 & 0.18 & ESTAR & -2237.14 to 2509.82 \\
\hline Finland & 0.41 & 0.00 & 0.22 & ESTAR & -2271.48 to 2536.76 \\
\hline France & 0.00 & 0.28 & 0.00 & LSTAR & -2378.94 to 2117.92 \\
\hline Germany & 0.01 & 0.32 & 0.00 & LSTAR & -2498.06 to 2195.28 \\
\hline Greece & 0.01 & 0.27 & 0.01 & LSTAR & -2384.55 to 2174.37 \\
\hline Ireland & 0.00 & 0.26 & 0.00 & LSTAR & -2438.91 to 2233.64 \\
\hline Israel & 0.00 & 0.35 & 0.00 & LSTAR & -2409.14 to 2241.28 \\
\hline Italy & 0.00 & 0.29 & 0.00 & LSTAR & -2388.42 to 2184.37 \\
\hline Japan & 0.00 & 0.37 & 0.00 & LSTAR & -2438.93 to 2266.54 \\
\hline Korea & 0.01 & 0.33 & 0.00 & LSTAR & -2399.08 to 2189.56 \\
\hline Netherlands & 0.00 & 0.28 & 0.00 & LSTAR & -2357.81 to 2147.82 \\
\hline New Zealand & 0.00 & 0.26 & 0.00 & LSTAR & -2448.82 to 2098.51 \\
\hline Norway & 0.29 & 0.01 & 0.24 & ESTAR & -2278.64 to 2488.32 \\
\hline Portugal & 0.00 & 0.31 & 0.01 & LSTAR & -2348.08 to 2156.74 \\
\hline Russia & 0.01 & 0.34 & 0.01 & LSTAR & -2391.35 to 2278.44 \\
\hline South Africa & 0.00 & 0.27 & 0.00 & LSTAR & -2407.13 to 2199.65 \\
\hline Spain & 0.00 & 0.29 & 0.00 & LSTAR & -2384.59 to 2202.43 \\
\hline Sweden & 0.37 & 0.00 & 0.25 & ESTAR & -2178.91 to 2548.77 \\
\hline Switzerland & 0.00 & 0.28 & 0.00 & LSTAR & -2437.81 to 2209.13 \\
\hline UK & 0.00 & 0.31 & 0.00 & LSTAR & -2388.73 to 2085.46 \\
\hline USA & 0.00 & 0.32 & 0.00 & LSTAR & -2418.07 to 2213.48 \\
\hline
\end{tabular}

Figures denote $p$-values

some countries, asymmetry is not only observed in relation to the magnitudes, but also in the direction of responses (i.e. positive or negative) as presented in Table 5.

This paper evaluates state dependency and asymmetry in the consumption responses by using a dataset from 25 countries, showing different economic, financial, and housing market characteristics. To generalize the results, this paper attempts to classify countries based on the following criteria (Case et al. 2005; Mishkin 2007): (1) direction, magnitude, state dependency (and its persistency importance) in income, interest rates, housing and financial wealth effects during high and low regimes (Tables 4 and 6; Fig. 3), (2) transition speeds in time variation (in Table 7, in Appendix 2), (3) asymmetry and its immediacy through nonlinear impulse response functions of consumptions (Figs. 1 and 2; Table 5). As indicated previously (see 3.1), to further improve the discussion, the countries are also classified in Table 8 (in Appendix 3) based on the multiple criteria. 


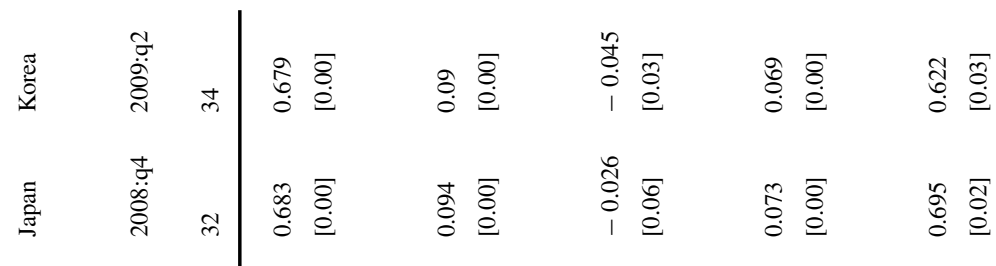

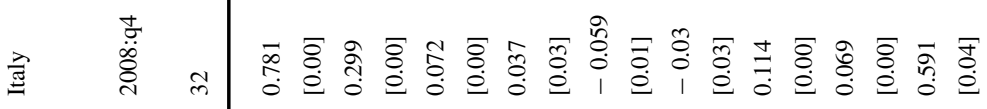

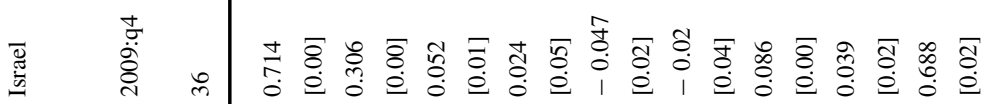

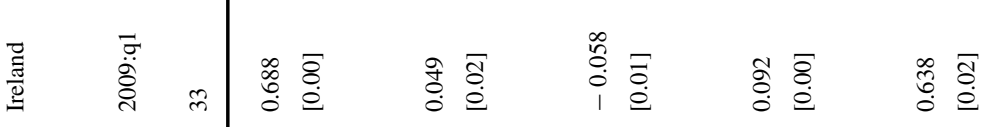

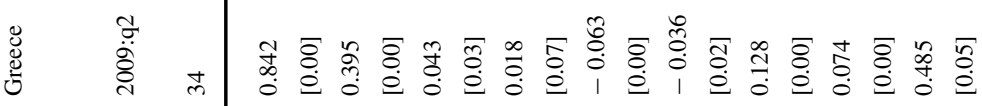

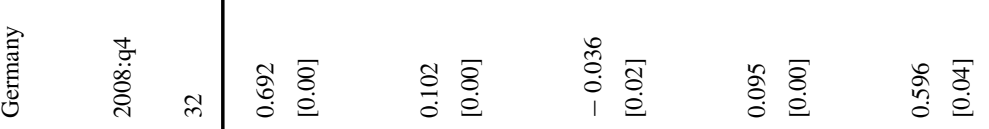

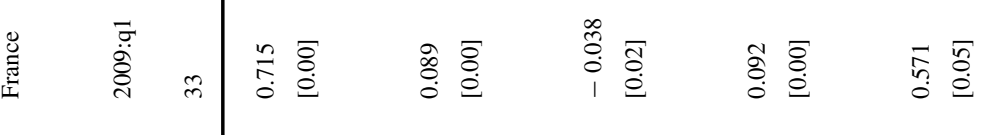

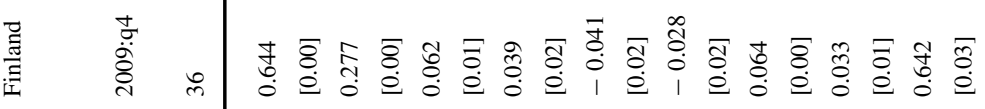

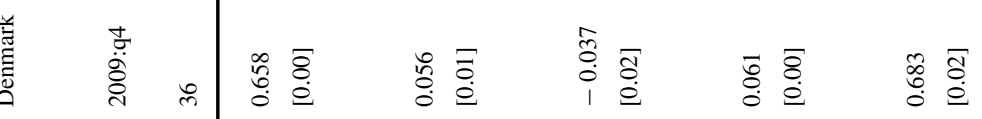

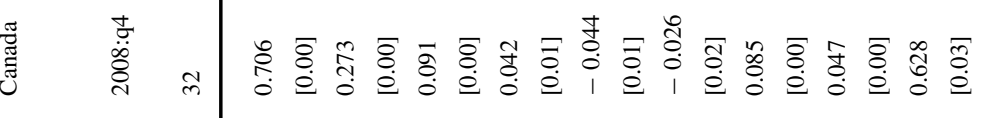

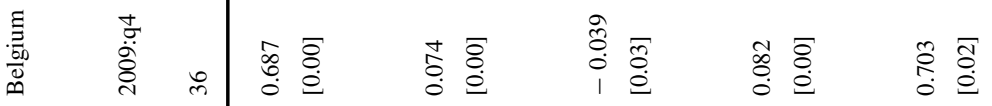

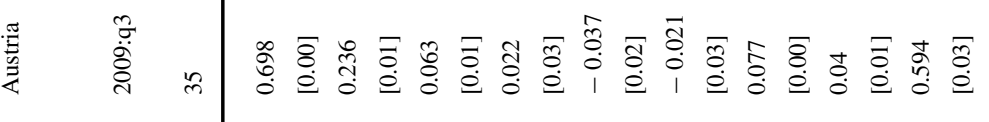

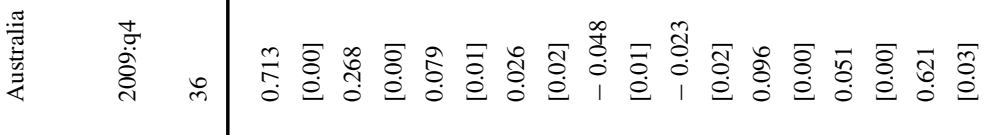

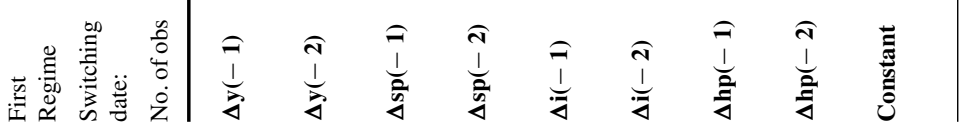




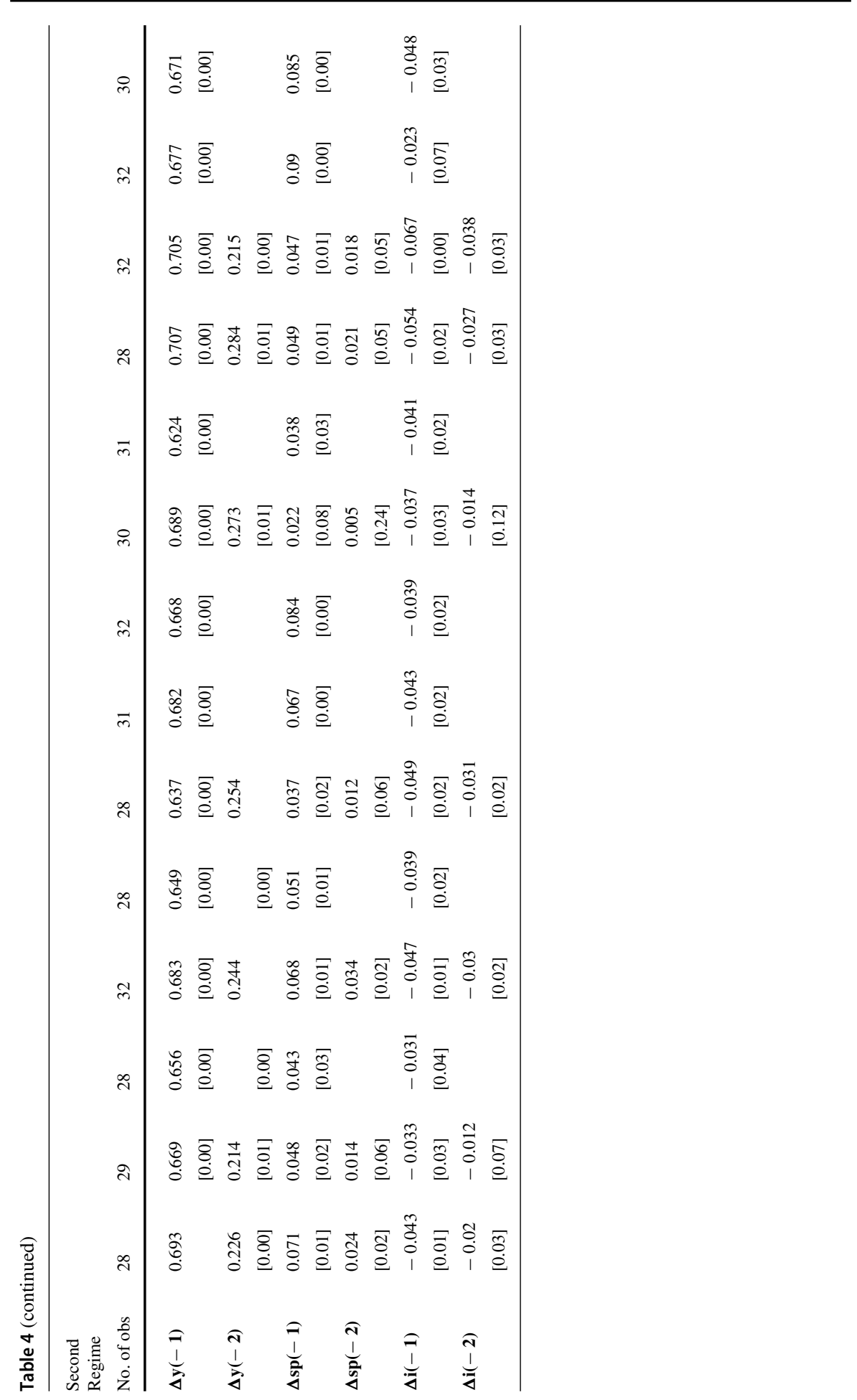




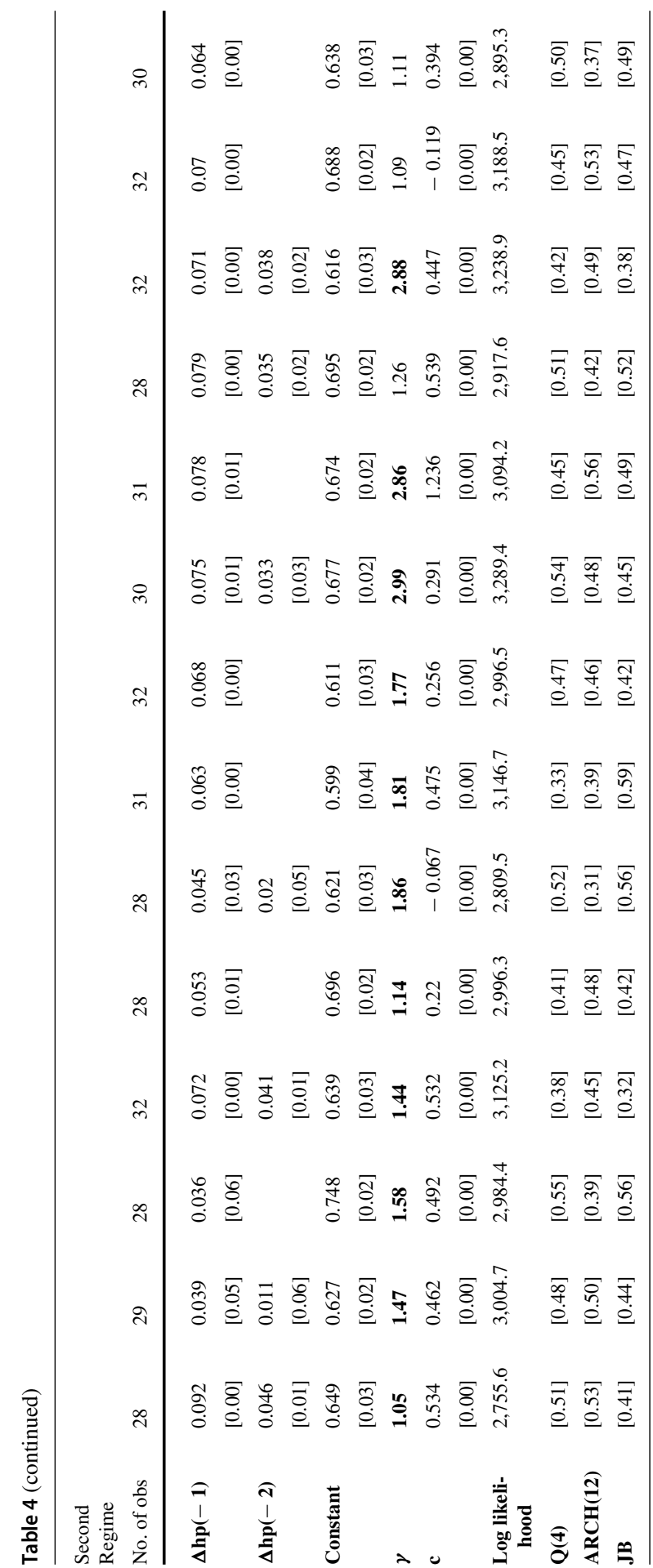




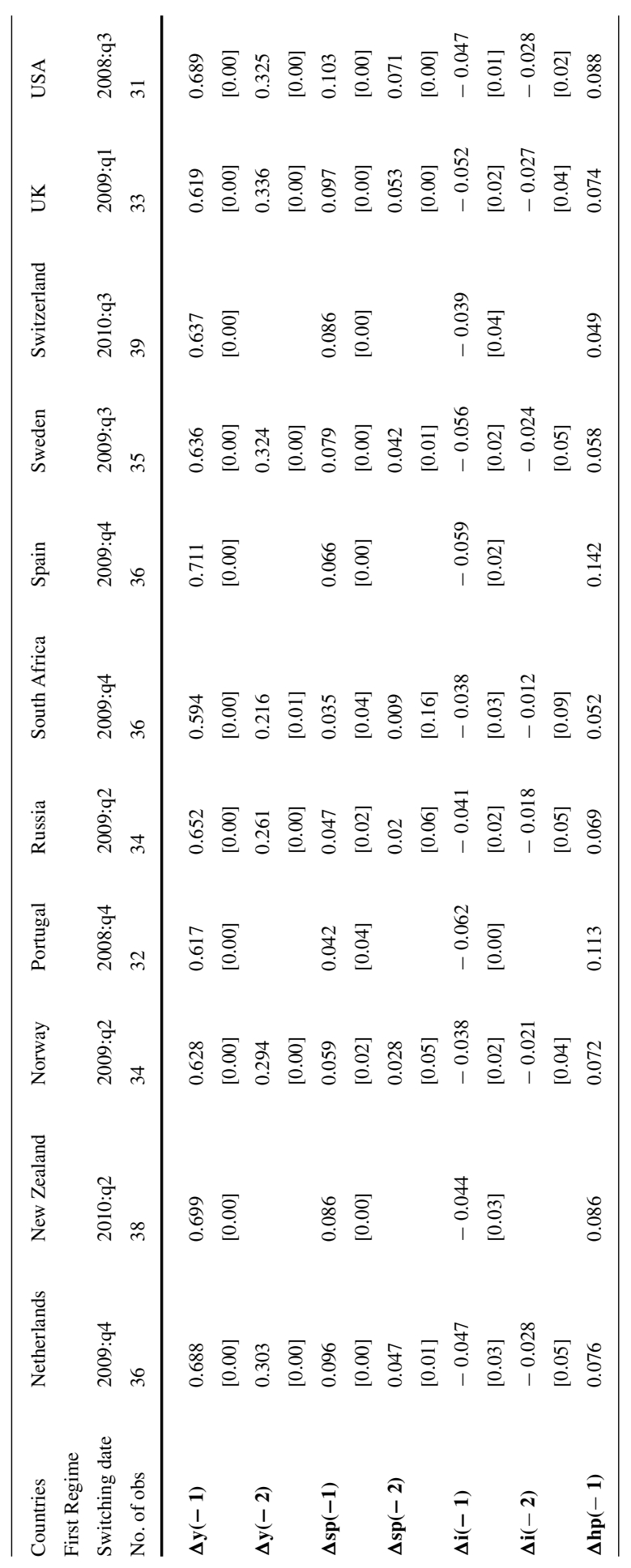




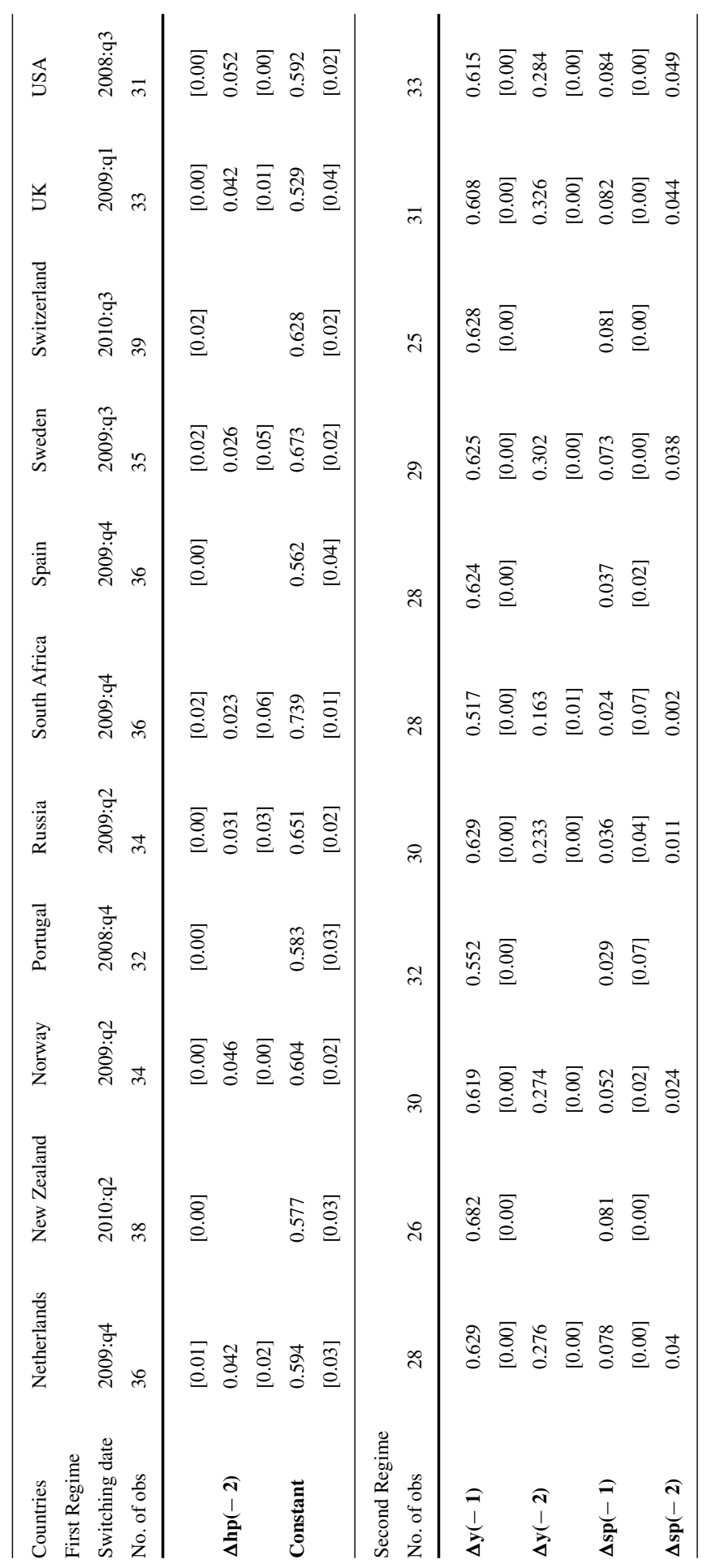




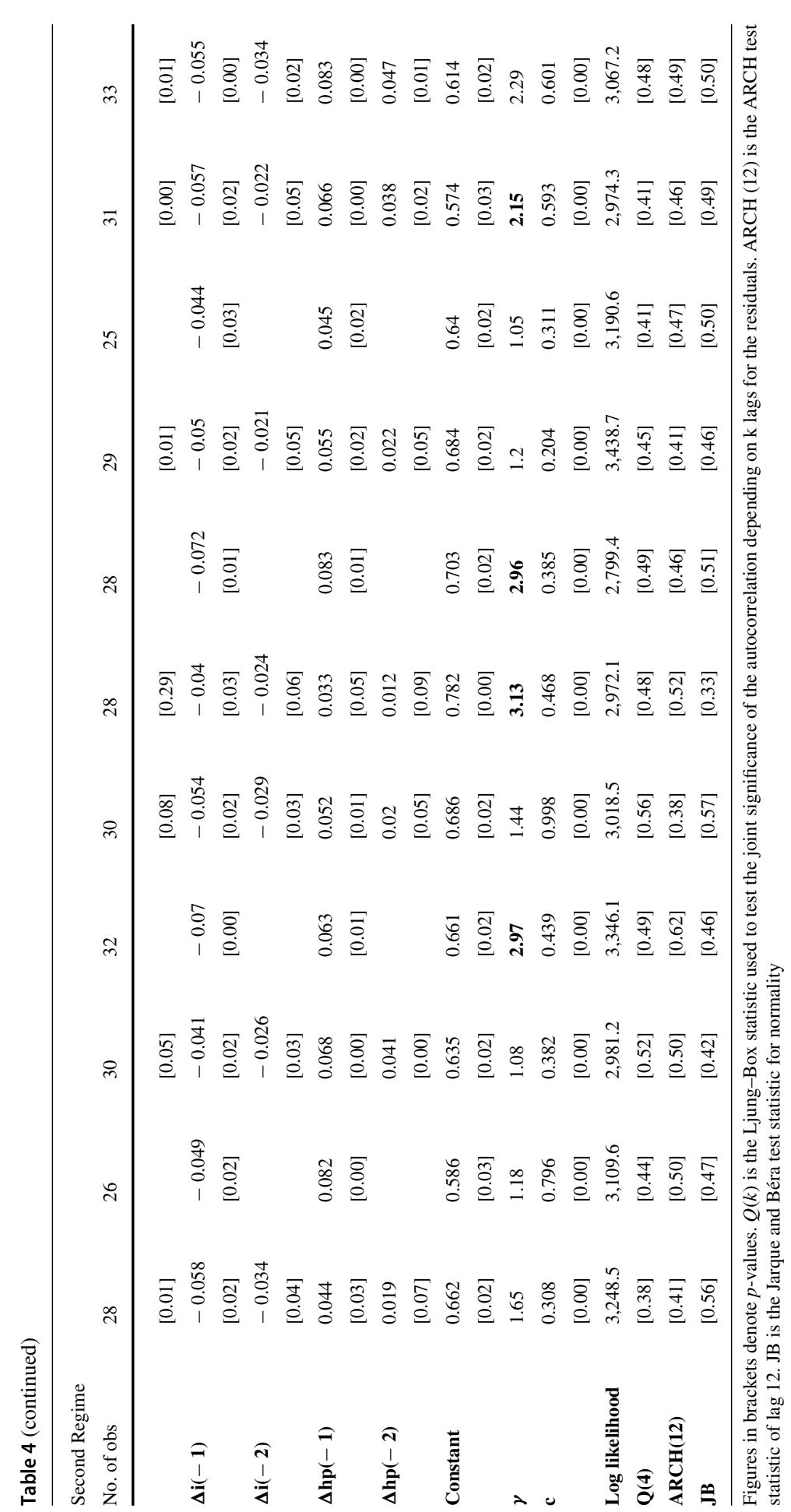



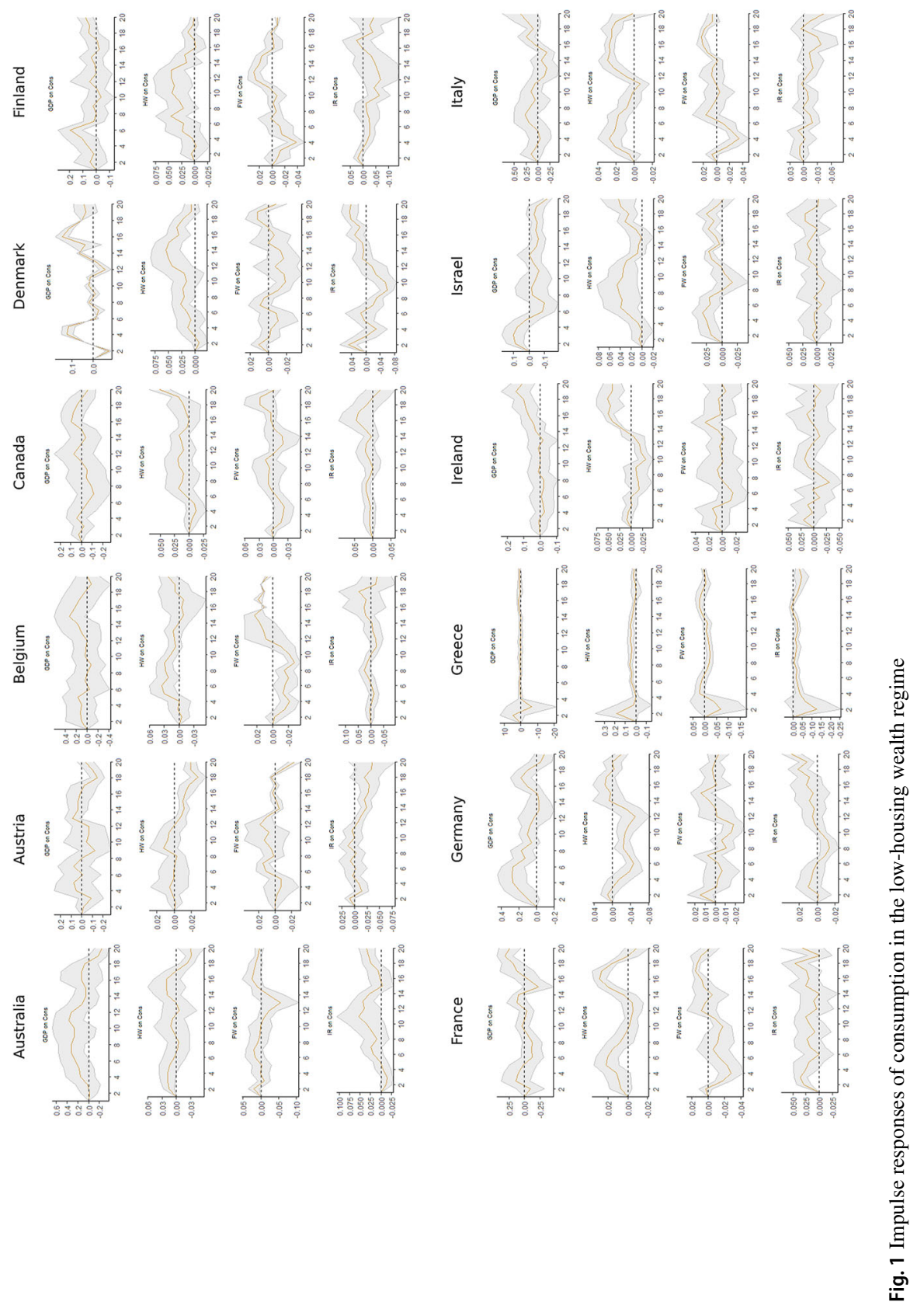

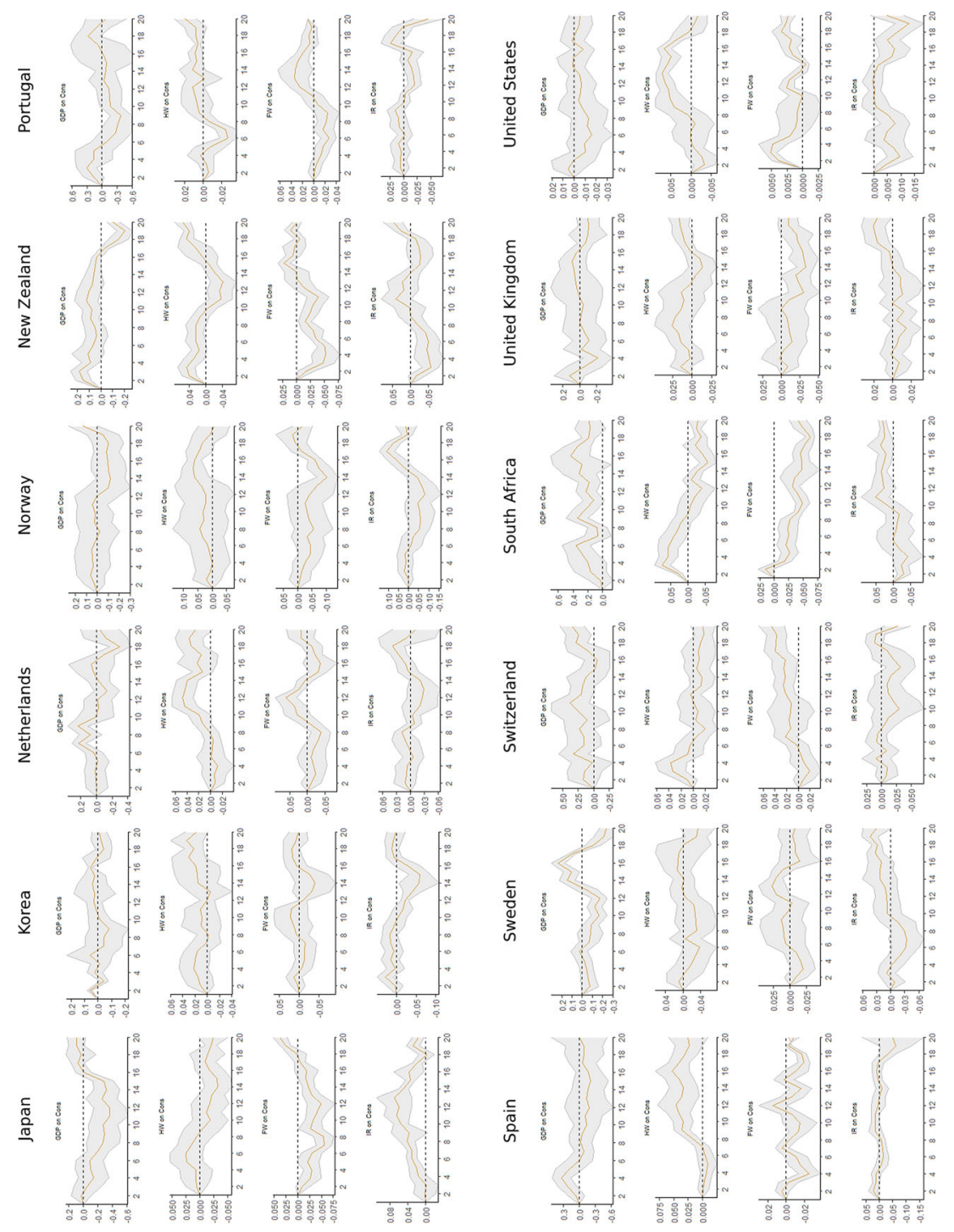

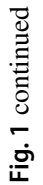



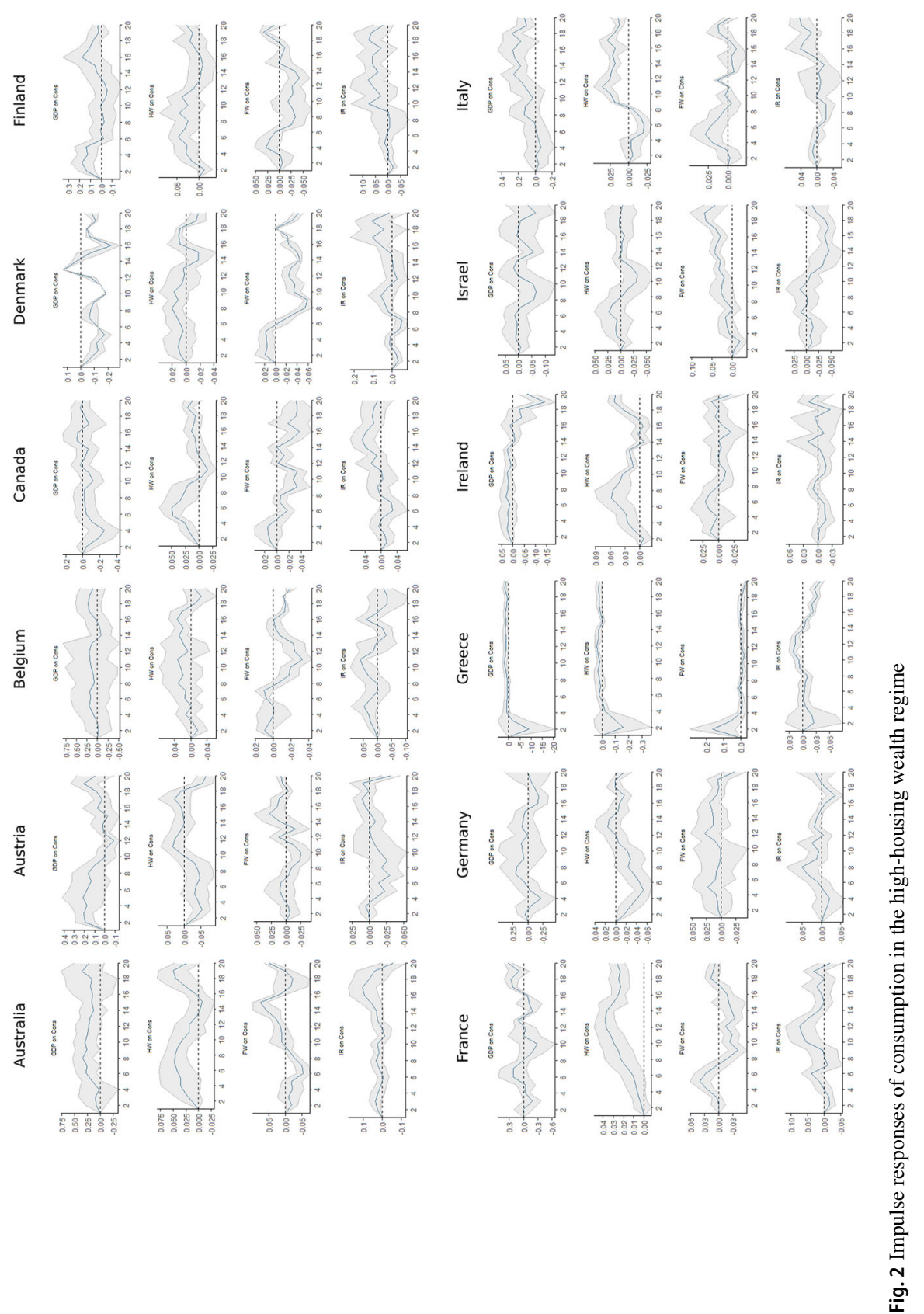

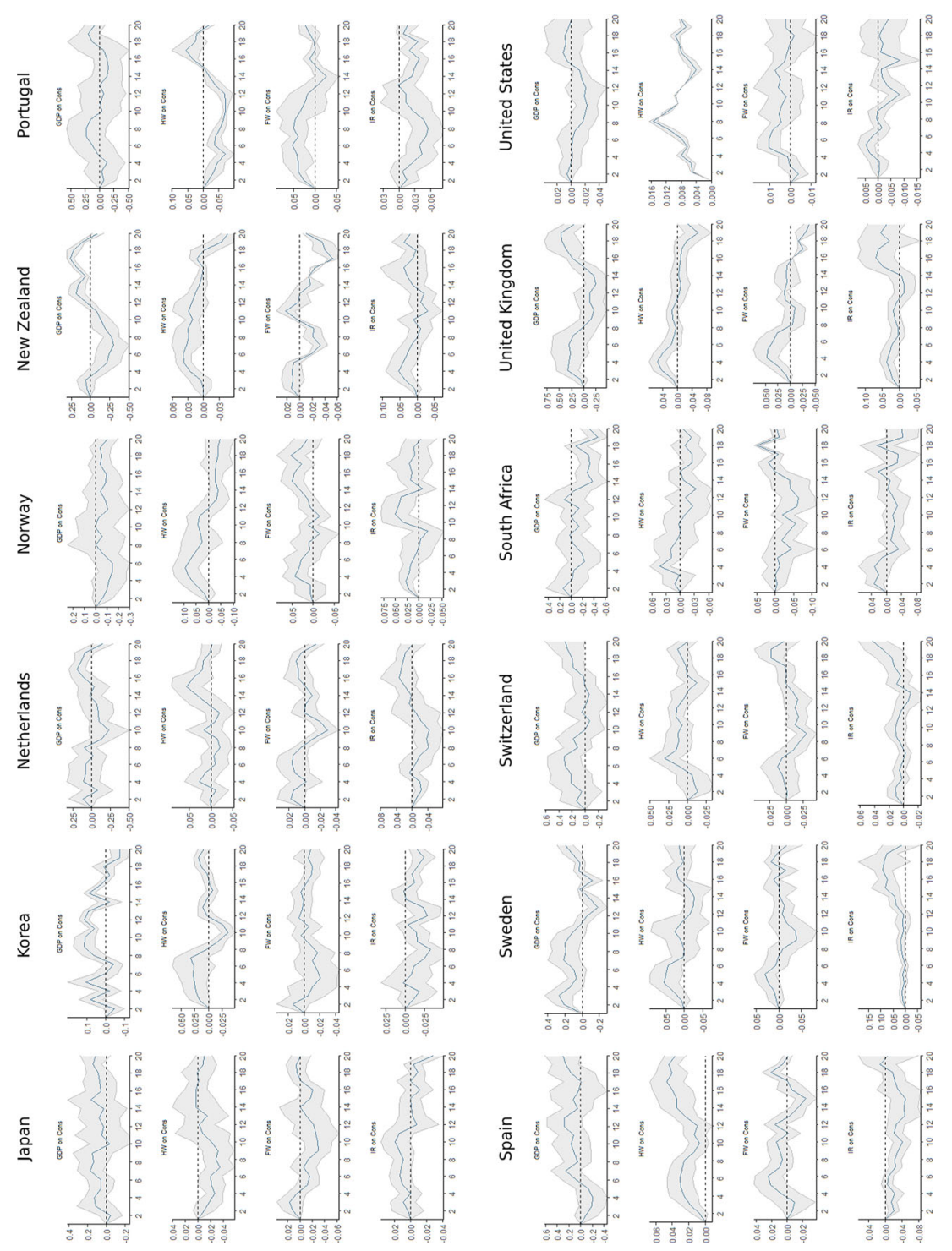

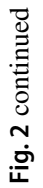


Table 5 Asymmetries in the direction of consumption responses to the shocks

\begin{tabular}{|c|c|c|}
\hline & In low-housing wealth regime & In high-housing wealth regime \\
\hline Income (GDP) & $\begin{array}{l}\text { In Australia, Germany, Italy, New Zealand, } \\
\text { Switzerland and South Africa, } \\
\text { consumption mostly responds positively } \\
\text { to one standard deviation shock from } \\
\text { income } \\
\text { In Israel, Japan, Portugal, Spain, Sweden } \\
\text { and USA, the response of consumption is } \\
\text { negative to one standard deviation shock } \\
\text { from income }\end{array}$ & $\begin{array}{l}\text { In Australia, Austria, Belgium, } \\
\text { Ireland, Italy, Japan, Korea, Spain, } \\
\text { Switzerland and UK, consumption } \\
\text { responds positively to income shocks } \\
\text { In Canada, Denmark, Israel, } \\
\text { Norway, South Africa and USA, } \\
\text { consumption responds negatively to } \\
\text { income shocks }\end{array}$ \\
\hline $\begin{array}{r}\text { Housing } \\
\text { Wealth }\end{array}$ & $\begin{array}{l}\text { In Australia, Belgium, Canada, Denmark, } \\
\text { Finland, France, Israel, Italy, Korea, } \\
\text { Netherlands, Norway, Spain, Portugal } \\
\text { and USA, impulse responses of } \\
\text { consumption to one standard deviation } \\
\text { shock from housing wealth is mostly } \\
\text { positive } \\
\text { In Germany, Sweden and Switzerland } \\
\text { consumption responds negatively to the } \\
\text { shocks from housing wealth }\end{array}$ & $\begin{array}{l}\text { In Australia, Belgium, Canada, } \\
\text { Denmark, Finland, France, Ireland, } \\
\text { Italy, New Zealand, Spain and USA, } \\
\text { consumption responds positively to } \\
\text { the shocks from housing wealth } \\
\text { In Germany, Israel, Japan, Portugal } \\
\text { and South Africa consumption } \\
\text { responds negatively to housing } \\
\text { wealth shocks }\end{array}$ \\
\hline $\begin{array}{c}\text { Financial } \\
\text { Wealth }\end{array}$ & $\begin{array}{l}\text { In Australia, Ireland, Israel, Italy, } \\
\text { Switzerland and USA, impulse responses } \\
\text { of consumption to financial wealth shocks } \\
\text { is mostly positive } \\
\text { In Belgium, Finland, France, Japan, } \\
\text { Netherlands, Norway, New Zealand, } \\
\text { Portugal, Spain, South Africa and UK, } \\
\text { consumption responds negatively to the } \\
\text { shocks from financial wealth }\end{array}$ & $\begin{array}{l}\text { In Germany, Israel, Italy, } \\
\text { Netherlands, Norway, Portugal, } \\
\text { Spain, UK and USA, consumption } \\
\text { responses positively to the shocks } \\
\text { from financial wealth } \\
\text { In Belgium, Canada, Denmark, } \\
\text { Finland, France, Japan, Korea, New } \\
\text { Zealand, Switzerland and South } \\
\text { Africa, consumption responds } \\
\text { negatively to the shocks from } \\
\text { financial wealth }\end{array}$ \\
\hline Interest Rates & $\begin{array}{l}\text { In Australia, Canada, France, Germany, } \\
\text { Japan, Portugal and Sweden, } \\
\text { consumption responds positively to the } \\
\text { shocks from interest rates } \\
\text { In Austria, Finland, Greece, Italy, } \\
\text { Norway, New Zealand, Switzerland, } \\
\text { UK and USA, consumption responds } \\
\text { negatively to interest rate shocks }\end{array}$ & $\begin{array}{l}\text { In Australia, Belgium, France, } \\
\text { Germany, Japan, Norway, New } \\
\text { Zealand, Sweden, Switzerland and } \\
\text { UK, consumption mostly responds } \\
\text { positively to the shocks from interest } \\
\text { rates } \\
\text { In Austria, Israel, Italy, Korea, } \\
\text { Netherlands, Portugal, Spain, South } \\
\text { Africa and USA, responds of } \\
\text { consumption to the shocks from } \\
\text { interest rates is mostly negative }\end{array}$ \\
\hline
\end{tabular}

(1) Bold characters indicate the countries in which the consumption responses are asymmetric in the direction to the shocks in different housing wealth regimes. (2) The countries being not referred in the table have mixed results for the direction of consumption responses 


$\begin{aligned} & \text { Financial Wealth Effect } \\ & \text { Countries }\end{aligned}$
- Germany (b)
- Japan (c)
- Netherlands (b)
- Sweden (c)
- Switzerland (c)
- UK (a)
- US (a)

Housing Wealth Effect
Countries
- Australia (c)
- Denmark (c)
- Finland (b)
- Greece (a)
- Ireland (a)
- Israel (c)
- Italy (a)
- Norway (c)
- Portugal (a)
- Russia (c)
- South Africa (a)
- Spain (a)
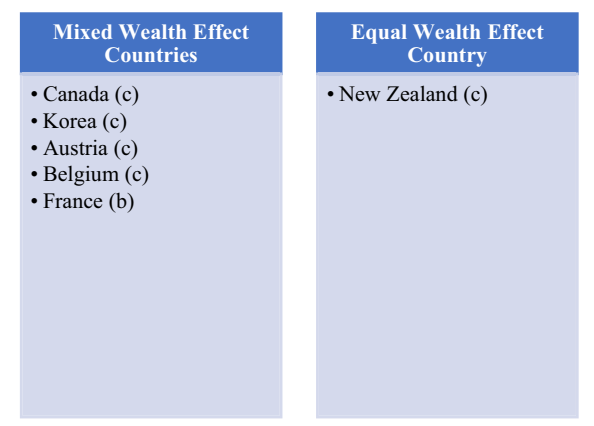

Fig. 3 Country classification: dominant wealth effect and transition speeds. Notes: (a), (b), and (c), respectively, show strong $(\gamma \geq 2)$, semi-strong (1.86 $\geq \gamma \geq 1.65)$, and weak $(1.65 \geq \gamma \geq 1)$ transition speeds (see Table 7 and Evidence Set 5 for a detailed discussion)

However, each piece of evidence requires particular policy attention; to keep the discussion within limits, we briefly discuss the most important evidence obtained. Below, we present policy implications based on the evidence/data provided in Tables 4 , 5, 6, 7, Figs. 1, 2, 3, and Appendices 1, 2, 3.

\subsubsection{Evidence Set \#1: direction and magnitude of income and interest rates}

Our first evidence set reports the direction-magnitude of the income and interest rates. In line with the theoretical expectations, we first report that housing wealth, financial wealth, and income have a positive, and interest rates have a negative association with households' consumption across all countries in both high and low regimes. These variables also generally show asymmetric and time-varying behaviour with mostly semi-strong or weak transition patterns (see Evidence Set 4/5/6).

In detail for the income and interest rate variables, in line with the literature, we secondly find that income is the most important determinant of the household consumption in both regimes across all countries. Like housing wealth and financial wealth, this variable also shows a time-varying and asymmetric behaviour and a higher impact during the expansionary period. The impact of the income is substantial (respectively, in first-expansionary-regime; in second-recessive-regime) in Greece (1.237; 0.962), Italy (1.080, 0.920), Israel (1.020; 0.991), the USA (1.014; 0.899), Australia (0.981; 0.919), and UK (0.955; 0.934).

Third, in line with the expectation (see, among others, Wright 1967; Boskin 1978; Mishkin 1976; Gylfason 1981), the inverse relation between interest rates and consumption across all sample countries is persistent evidence (Eggertsson et al. 2017; Gourinchas and Rey 2018). Taken into account real interest rates have been declining during our observation period due to the policies of central banks and market dynamics (Del Negro et al. 2019), we may argue that increases in consumption in a low-real interest rate (and rising market) environment would be related to gradually removing liquidity constraints and increasing leverage for households. Moreover, the impact of interest rates also shows a country-basis time-varying and asymmetric pattern. It is generally smaller in all countries when compared to the impact of housing wealth 
and financial wealth. However, interestingly, the impact of interest rates is higher than financial wealth in Greece, Ireland, Portugal, and South Africa in the high and low regimes, as well as in Israel, Italy, Russia, Spain, and Finland in the low regime. The impact of interest rates is also relatively higher in the following countries (respectively, in first regime; in second regime): Italy $(0.89 ; 1.05)$, Sweden $(0.80 ; 0.71)$, UK $(0.79 ; 0.79)$, USA $(0.75 ; 0.89)$, Australia $(0.071 ; 0.63)$, Canada $(0.070 ; 0.77)$, Finland $(0.069 ; 0.80)$, and Greece $(0.99 ; 0.051)$.

Regarding to implications of the first evidence set, we speculate that (1) higher and equally distributed income may result in less time-varying asymmetric consumption responses specifically during the recessionary period (see Husby 1983), (2) countries that show more interest rate sensitivity may implement their consumption-related interest rate policies very cautiously. Potential interest rate risks in those countries may result in negative consumption shocks due to the documented sensitivity.

\subsubsection{Evidence Set \#2: patterns of housing and financial wealth effects}

Fourth, as one of the main findings of this research, in line with the literature, the housing wealth effect is generally larger than the financial wealth effect in most of the countries, irrespective of the state dependencies and asymmetries across different market regimes (see Table 4). For example, housing wealth has a significant impact on consumption, vis-à-vis the financial wealth effect (in the first and second regimes, respectively) in the following bank-based, albeit declining, housing ownership ratio countries: Greece $(0.202 ; 0.108)$, Italy $(0.183 ; 0.109)$, Spain $(0.142 ; 0.083)$, Israel $(0.125 ; 0.114)$, and Portugal $(0.113 ; 0.063)$.

It may be interesting to note that as the financial wealth effect countries, the USA and the UK have also sizable housing wealth effects. Our findings also suggest that both wealth effects show a time-varying and asymmetric behaviour (i.e. see Case et al. 2011; Simo-Kengne et al. 2013; Mignon and Dufrénot 2004; Jawadi and Leoni 2012; Jawadi et al. 2017). However, while financial wealth declines significantly in the recessionary regime in some countries, the housing wealth effect generally shows relatively less decline across different market regimes. In line with the literature, this pattern implies a persistency in the positive housing wealth effect irrespective of the market regimes considered (see Case et al. 2005; 2011; Sousa 2005).

\subsubsection{Evidence Set \#3: classifying countries: size of wealth effect and transition speeds}

The roles of financial wealth and housing wealth in consumption should be assessed on a country and market regime basis (Jawadi et al. 2017). Therefore, fifth, the present study attempts to classify countries depending on the state dependency (Table 4), transition speed (Table 7), asymmetry (Figs. 1, 2, Table 5) and argue that countryspecific dominant wealth effect classification (Fig. 3) with the above information set would be a useful tool in policy-making.

We utilize the following approach to develop dominant wealth effect classification: if financial (housing) wealth effect is the primary wealth effect channel in consumption in both regimes for the country, we classify it as a financial (housing) wealth 
effect country. For example, having consistently higher housing wealth effect coefficient values than financial wealth effect coefficient values across time and different market regimes implies that this is a housing wealth effect country, or vice versa. If the coefficient values show a significant time-varying feature across different market regimes (Evidence Set 4/5), we classify this country as a mixed wealth effect country. In this case, we assume that the country's dominant wealth effect channel is unclear, or it may change depending on the time and market regime. Figure 3 shows country classifications according to dominant wealth effects with also transition speed in time variation, as the summary information for Evidence Set 5 and Table 7.

Hence, the analysis considers Germany, Japan, Netherlands, Sweden, Switzerland, the UK and the USA as the financial wealth effect countries, and Australia, Denmark, Finland, Greece, Ireland, Israel, Italy, Norway, Portugal, Russia, South Africa, and Spain as the housing wealth effect countries. Interestingly, housing and financial wealth effects in New Zealand are equal in the first and the second regimes. Finally, Canada, Austria, Belgium, France, and Korea are classified as the mixed wealth effect countries, where their dominant wealth effect shows relatively higher time-varying features.

Sixth, our findings with the information provided in Appendix 3 also suggest that financial (housing) wealth effect countries mostly show market (bank)-based features (i.e. see Ludwig and Sløk 2004; Case et al. 2005; Slacalek 2009). Mixed wealth effect countries have the combinations of bank- and market-based features. As the limitation of this study, the model specification does not permit us to make a proper generalization for which factor(s) might play a role in this classification framework such as the level of housing market and stock market completeness, high- and lowincome levels, being an Anglo-Saxon country or locating in continental Europe, or in (non-) euro area (Peltonen et al. 2012; Albacete and Lindner 2017).

The policymakers may utilize the observation in the above classification attempt into their housing and stock markets policies effective on consumption (and hence economic growth). For example, policymakers in housing (financial) wealth effect countries may specifically focus on housing (stock) market policies to induce consumption during specifically recession periods. However, policymakers should be aware of the risks of contradictory stock and housing market policies in mixed wealth effect countries. Although housing and stock markets generally show co-movements in the case of developed countries, the sector-specific fine-tuning policies, depending on the level of time-varying asymmetry, may further improve consumption-led growth (see Evidence Set 4/5/6).

\subsubsection{Evidence Set \#4: time-varying behaviour of model variables}

Seventh, the findings further suggest that income, stock price, house price, and interest rate show a time-varying behaviour during the periods of positive and negative shocks in most of the countries. As the general policy implication, we suggest that countries may implement their consumption (and hence economic growth) policies during expansion and recession periods by also using expected time-varying effects of income, housing/stock prices, and interest rates.

Eight, differences in the coefficient values in the first and second regimes also provide additional information. In this respect, data suggest that state dependent income, 
housing wealth, and financial wealth effects are high (low) during expansionary (recessive) periods across all countries (Apergis and Miller 2006; Case and Quigley 2008). Therefore, partly in line with Berger et al. (2017) with a larger sample and additional variables, we cautiously conclude that during expansionary (recessive) periods, house and stock prices may result in larger (lower) value increases in housing and stock holdings and, hence, consumption responses. By contrast, the evidence of relatively lower coefficient values in the recessionary regime suggests that consumers do not reduce their consumption substantially when they lose their income and specifically housing wealth in recessionary periods as much as they increase it when their income and wealth increase in expansionary regimes (Case et al. 2005; 2011).

We define that the interest rate exposure of consumption is greater in the expansion regime only in Australia, Austria, Belgium, Greece, Ireland, Japan, Sweden, while it is equal in the UK. In the rest of the countries, the interest rate exposure of consumption is lower in the expansion regime than in the recession regime. The higher negative impact of interest rates during recessive periods possibly implies substitution effects for most of the countries (see Hviid and Kuchler 2017). This result may suggest that increases in interest rates lead to a greater decline in consumption in a recessionary regime, vis-à-vis in an expansionary regime. In those countries, policymakers may take into account time-varying responses of consumption to interest rates during recessionary regimes.

The country-level analyses a time-varying behaviour of the variables which present a rich information set. For example, data generally suggest a less significant timevarying behaviour in income variables, except in the cases of Spain, Portugal, and Greece. Apart from South Africa, Greece, and Portugal, a time-varying behaviour of interest rates does not have any significant effects on consumption. Data also suggest that time-varying behaviours of housing and financial wealth effects are more significant in bank-based and financially-relatively-less developed countries, such as Greece, Portugal, South Africa, and Spain. Country-level time variations may cautiously suggest that market completeness and economic development may play substantial roles in the magnitudes of time variations.

\subsubsection{Evidence Set \#5: transition speeds of parameters}

Ninth, the estimated smooth parameter, $\gamma$, takes values higher than two, implying a strong transition ${ }^{9}$ from one regime to another in certain countries, such as in Greece, Ireland, Italy, Portugal, South Africa, Spain, the UK, and the USA, while in other

\footnotetext{
9 In strong transition countries, the estimates indicate strong changes by showing how housing prices impact consumption (the housing wealth effect) across regimes. For instance, in the case of Greece, when changes in consumption $(\Delta c)$ are higher than 0.291 , the exposure to the housing price changes coefficient is 0.202 (the sum of 0.128 and 0.074 ). In contrast, in the other regime, the exposure coefficient of housing prices turns out to be 0.108 (the sum of 0.075 and 0.033 ). Evidently, the housing prices exposures of consumption are different across different regimes. In other words, in the case of a recessionary housing market, consumption reacts stronger than in the case of a bullish housing market, indicating the significance of the housing wealth effect for Greek consumers. By contrast, in the cases of a smooth $\gamma$ parameter, the exposure is not substantially high. For instance, in the case of Switzerland, with a low $\gamma$ smoothing parameter (1.05), the housing prices exposure of consumption remains relatively similar across both regimes, 0.049 versus 0.045 .
} 
cases, such as in Australia, Japan, Korea, New Zealand, Switzerland, Norway, Denmark, and Sweden, the $\gamma$ parameter takes low values (close to one), suggesting a weak transition from one regime to another. Among the remaining countries, Finland, France, Germany, and Netherlands' parameter values are ranging from 1.65 to 1.87, implying a semi-strong transition (Fig. 3; Table 7). This categorization is not an outcome of modelling but recommended by the authors for a practical purpose showing the distinction between strong and weak transitions.

This evidence set suggests that policymakers may implement their consumption sensitive stock and housing market policies based on the magnitude of this transition process. As an implication, housing market policies in housing wealth effect countries having also a strong transition pattern may require a continuous attention on housing market fundamentals. Policymakers in financial wealth effect and weak transition countries may have relatively less concern on the impact of negative shocks on house prices, except in those countries, which have a sizable housing wealth effect, such as the USA, the UK and New Zealand.

Because our modelling structure does not permit to assess the determinants of transition speed, we attempt to classify the sample countries based on their selected economic and financial characteristics and then try to develop a linkage between these features and transition classification. According to this experimental approach, the above evidence may imply that strong transition countries generally show pure or strong (in the case of the UK and the USA) housing wealth effect, relatively higher sensitivity on interest rates, and high, albeit declining, housing ownership ratio characteristics. Strong transition countries also show a mix of big-small and bank- and market-based characteristics (see Appendix 3). Among these countries, Greece, Italy, Spain, and Portugal show statistically significant and high levels of state dependency (Table 4). Moreover, while the UK and the USA have positively evolving economic conditions during the post-GFC period, the remaining strong transition countries have shown high economic risks during and after the GFC. By contrast, weak transition countries show a relatively low sensitivity on interest rate changes (except Australia), a mix of big or small, housing or financial wealth effect country, and bank- or market-based economy characteristics. Except for Norway, these countries have comparatively lower housing ownership ratios, ranging from 51 to $65 \%$. However, in Japan and Korea, the housing ownership ratios have been increasing during the period under consideration.

\subsubsection{Evidence Set \#6: asymmetries based on nonlinear impulse response functions}

Tenth, the results of the nonlinear impulse response functions imply that consumption responses to shocks may depend on the housing wealth regime, the sources of shock, and the subject country. In general, the results indicate that consumption responds immediately to shocks in all variables in both the low- and high-housing wealth regimes across all countries, while the effects of shocks last 20 quarters. There are two exceptions: Greece and Sweden. In Greece, income (GDP), housing wealth and financial wealth shocks immediately affect consumption in only four quarters in both regimes. After four quarters, the effects of shocks on consumption disappear. However, the shocks from interest rates affect consumption until 20 quarters. As another exception, 
in Sweden, interest rate shocks start to affect consumption after 12 quarters in the high-housing wealth regime.

Eleventh, the responses of consumption to shocks from all variables are asymmetric in high- and low-housing wealth regimes. However, in order to highlight one of the most interesting results, we group the countries in which the asymmetry is observed in the direction of the responses as positive or negative rather than in the magnitudes solely. In this respect, in both low- and high-housing wealth regimes, only in Israel and Portugal consumption shows asymmetric responses in the direction to housing wealth. For instance, in Israel, consumption responses are positive to the shocks arising from housing wealth in the low-housing wealth regime; however, in the high-housing wealth regime, consumption responses are negative to the shocks from housing wealth. Interestingly, we observe a relatively stronger asymmetry in the direction in financial wealth variable. In this respect, in both low- and high-housing wealth regimes, in Netherlands, Norway, Portugal, Spain, the UK, and in Switzerland, consumption shows asymmetric responses in (positive or negative) direction to financial wealth. In a country-level analysis, Switzerland, the UK, and more specifically, Portugal, show rather stronger asymmetries vis-a-vis other countries (see Table 5, Figs. 1 and 2). Our model specification does not explain why housing wealth and financial wealth may generate an opposite response in consumption during different market regimes. One explanation could be that country-specific factors may play a substantial role in this result. A second explanation could be that economic cycles may have serious adverse effects on the behaviour of housing and financial wealth. A third explanation could be that the lack of efficient policy framework during high and low market regimes may support the presence of opposite responses in relevance to the wealth effect.

\section{Conclusion}

Without considering the presence of nonlinearity of consumption, the differentials in stock prices, housing prices, income, and interest rates exposures may be ignored, which constitutes the main novelty of this work. The study primarily aimed to investigate whether, and to what extent, there were state dependency and asymmetry between housing wealth, financial wealth, interest rate, income, and consumption during expansionary and recessionary periods by employing STAR family models and nonlinear impulse response functions based on the local projections for 25 mostly OECD countries over the period from 2000 to 2016. As the methodological improvement, the latter modelling is the first in the asymmetric consumption and wealth effect empirical literature. The practical policy contribution of the study is that our evidence sets let us classify countries depending on their dominant wealth effect, and the characteristics of time variation, asymmetry, and transition speed in state dependency for income, interest rates, house prices, and stock prices during expansionary and recessive periods. The major findings of the investigation, along with their implications, can be summarized below.

First, in line with the literature, the results confirm that housing wealth, financial wealth, and income have a positive and interest rates have a negative association 
with household consumption during expansionary and recessive periods. Among these variables, income is the most important determinant of household consumption and the impact of interest rates is generally smaller (i.e. see Siokis 2005; Kapoor and Ravi 2009; Hviid and Kuchler 2017). The findings also suggest that housing wealth effects show persistency and generally larger than financial wealth effects in most of the countries across both regimes (i.e. see Catte et al. 2004; Sousa 2005; Bostic et al. 2009; Jawadi and Léoni 2012; Case et al. 2013; Bunn et al. 2018).

Second, as our main finding in all sample countries during positive and negative shock periods: nonlinear impulse response functions and STAR family models, respectively, imply that income, stock prices, interest rates, and house prices exposures of consumption generally show significant, immediate, persistent asymmetric and also persistent and an important time-varying behaviour (i.e. Simo-Kengne et al. 2013; Mignon and Dufrénot 2004; Jawadi and Sousa 2014; Jawadi et al. 2017; Berger et al. 2017; Hviid and Kuchler 2017). Third, we also find that the time-varying housing and financial wealth effects were generally high (low) during expansionary (recessionary) periods for all countries. Moreover, the evidence also suggests that there are some strong, but mostly semi-strong and weak transitions in independent variables during different market regimes. Interestingly, in line with Catte et al. (2004), Case and Quigley (2008), Case et al. (2005; 2011) and Jawadi and Leoni (2012), among others, the evidence implies that consumers do not reduce their consumption substantially when they lose their income and wealth in a recessionary period. Fourth, according to their country-specific dominant wealth effect, we classify, among others, Germany, Japan, the UK, and the USA as the financial wealth effect countries and Australia, Denmark, Greece, and Ireland as the housing wealth effect countries. As an interesting extension for this evidence, it is observed that financial (housing) wealth effect countries mostly show market (bank)-based features in line with the studies in the literature. As a general conclusion for policy-making, knowing the dynamics of country-specific dominant wealth effect, the features of state dependency, asymmetry, the level of transition speed would be supportive for monetary and fiscal policies.

We argue that the motives of an asymmetric consumption behaviour may involve both rational and physiological features. For example, it may be rational to observe a declining consumption during recessive period due to declining market values of housing wealth and financial wealth. However, despite specifically declining income levels, less decline in consumption over the recessive period may also imply some physiological elements (Thaler 1990, 1994; Genesove and Mayer 2001). This type of time-varying behaviour in the consumption may be explained by protecting (improving) the social status and the standard of living during recession (expansion) periods. The possible underlying reasons for this behaviour are also explained by absolute and relative income effects in Coskun et al. (2020). According to Duesenberry's (1949) consumption theory and as it is stated in Palley (2010), an increase in income and wealth may induce an increase in consumption only if the increase in household income raises a household's relative income position rather than her absolute income. Therefore, households with different amounts of wealth may respond differently to the same aggregate shock which may also deepen the asymmetry in the consumption function. 
Taken into account the emerging housing and stock market-specific behavioural literature, we may expect that behavioural wealth effects may get more attention in the literature. In this respect, we propose that future research efforts may concentrate on investigating (1) the impact of wealth effect connected with the signalling effect on the consumption asymmetry during expansionary and recessionary periods, (2) country-level determinants of dominant wealth effect, time variation, asymmetry, and transmission, (3) developing fiscal and monetary tools for consumption policy depending on the behavioural aspects of state dependency, asymmetry, and transition metrics.

Acknowledgements The authors thanks to three anonymous referees, whose remarks have been very helpful in preparing the final version of the paper. We also thank to Esen Alp Erbay for her proofread contribution.

\section{Declarations}

Conflict of interest Authors declare that they have no conflict of interest.

Human and animal rights This article does not receive research grant and contain any studies with human participants or animals performed by any of the authors.

\section{Appendix 1}

See Table 6. 


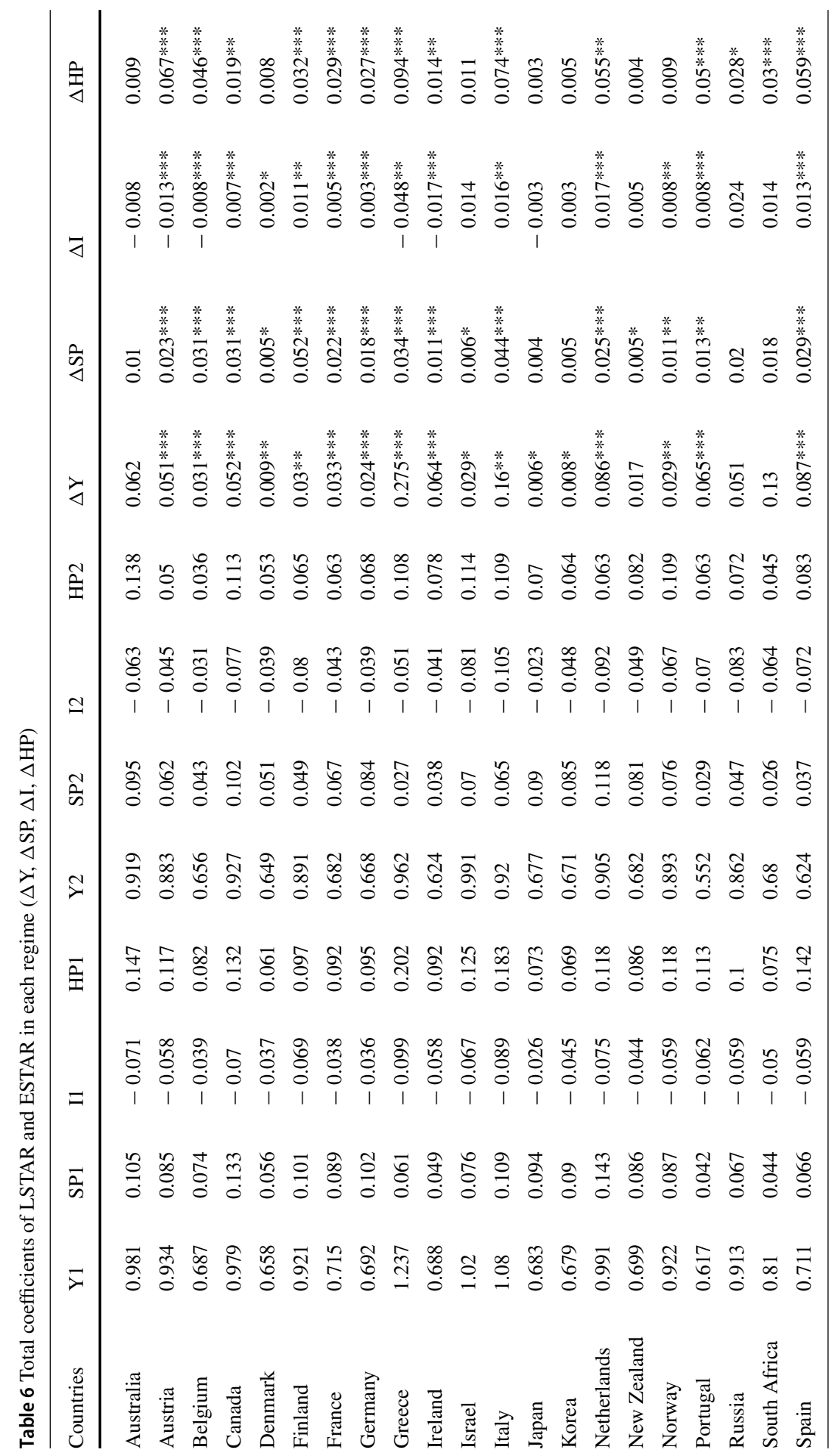




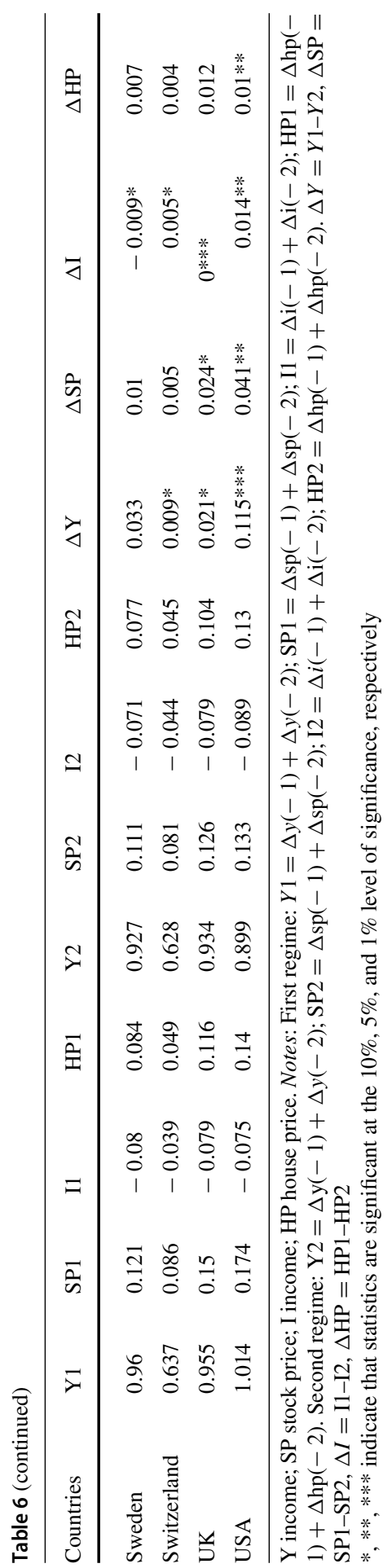




\section{Appendix 2}

See Table 7.

Table 7 Classification of countries based on the transition speed

\begin{tabular}{|c|c|c|c|c|}
\hline Country $/[\gamma]$ & $\Delta \mathrm{Y}$ & $\Delta \mathrm{SP}$ & $\Delta I$ & $\Delta \mathrm{HP}$ \\
\hline Australia [1.05] & Greece*** $(0.00)$ & Finland $* * *(0.00)$ & Greece $^{* *}(0.01)$ & Greece*** $(0.00)$ \\
\hline Austria [1.47] & Italy** (0.01) & Italy*** $(0.00)$ & Russia (0.13) & Italy*** $(0.00)$ \\
\hline Belgium [1.58] & $\begin{array}{l}\text { South Africa } \\
(0.15)\end{array}$ & $\mathrm{USA}^{* *}(0.03)$ & $\begin{array}{l}\text { Netherlands*** } \\
\quad(0.00)\end{array}$ & Austria*** $(0.00)$ \\
\hline Canada [1.44] & $\mathrm{USA}^{* * *}(0.01)$ & Greece $^{* * *}(0.00)$ & Ireland $* * *(0.00)$ & Spain*** (0.00) \\
\hline Denmark [1.14] & Spain*** (0.00) & Canada*** $(0.00)$ & Italy** (0.01) & $\begin{array}{l}\text { Netherlands*** } \\
\quad(0.00)\end{array}$ \\
\hline Finland [1.86] & $\begin{array}{l}\text { Netherlands*** } \\
\quad(0.00)\end{array}$ & $\begin{array}{l}\text { Belgium } * * * \\
\quad(0.00)\end{array}$ & $\mathrm{USA}^{* *}(0.02)$ & $\begin{array}{l}\text { Portugal } * * * \\
\quad(0.00)\end{array}$ \\
\hline France [1.81] & $\begin{array}{l}\text { Portugal } * * * \\
\quad(0.00)\end{array}$ & Spain*** (0.00) & $\begin{array}{l}\text { South Africa } \\
\quad(0.15)\end{array}$ & $\begin{array}{l}\text { Belgium } * * * \\
\quad(0.00)\end{array}$ \\
\hline Germany [1.77] & Ireland $* * *(0.00)$ & $\begin{array}{l}\text { Netherlands } * * * \\
\quad(0.00)\end{array}$ & Israel (0.18) & Finland $* * *(0.00)$ \\
\hline Greece [2.99] & Australia (0.16) & $\mathrm{UK}^{*}(0.08)$ & Austria*** (0.00) & $\begin{array}{l}\text { South Africa*** } \\
\quad(0.00)\end{array}$ \\
\hline Ireland [2.86] & Canada*** $(0.00)$ & Austria*** (0.00) & Spain*** (0.00) & France $* * *(0.00)$ \\
\hline Israel [1.26] & Russia (0.16) & France $^{* * *}(0.00)$ & Finland $* *(0.01)$ & Russia* (0.09) \\
\hline Italy [2.88] & Austria*** $(0.00)$ & Russia (0.15) & Sweden* (0.07) & $\begin{array}{l}\text { Germany } * * * \\
(0.00)\end{array}$ \\
\hline Japan [1.09] & France $* * *(0.00)$ & $\begin{array}{l}\text { South Africa } \\
\quad(0.19)\end{array}$ & Australia (0.14) & Canada** $(0.01)$ \\
\hline Korea [1.11] & Sweden (0.14) & $\begin{array}{l}\text { Germany } * * * \\
(0.00)\end{array}$ & $\begin{array}{l}\text { Portugal } * * * \\
(0.00)\end{array}$ & Ireland $^{* *}(0.02)$ \\
\hline $\begin{array}{l}\text { Netherlands } \\
\text { [1.65] }\end{array}$ & $\begin{array}{l}\text { Belgium*** } \\
\quad(0.00)\end{array}$ & Portugal** $(0.02)$ & Norway** (0.04) & UK (0.12) \\
\hline $\begin{array}{l}\text { New Zealand } \\
\text { [1.18] }\end{array}$ & Finland $* *(0.01)$ & Ireland $* * *(0.00)$ & $\begin{array}{l}\text { Belgium } * * * \\
\quad(0.00)\end{array}$ & Israel (0.15) \\
\hline Norway [1.08] & Israel* $(0.07)$ & Norway** $(0.03)$ & Canada*** $(0.00)$ & $\mathrm{USA}^{* *}(0.04)$ \\
\hline Portugal [2.97] & Norway** (0.01) & Sweden (0.13) & N. Zealand (0.11) & Australia (0.14) \\
\hline Russia [1.44] & $\begin{array}{l}\text { Germany } * * * \\
(0.00)\end{array}$ & Australia (0.16) & France*** $(0.00)$ & Norway (0.14) \\
\hline $\begin{array}{c}\text { South Africa } \\
{[3.13]}\end{array}$ & $\mathrm{UK}^{*}(0.06)$ & Israel* $^{*}(0.09)$ & $\begin{array}{l}\text { Switzerland* } \\
\quad(0.06)\end{array}$ & Denmark (0.13) \\
\hline Spain [2.96] & N. Zealand (0.15) & Denmark* $(0.08)$ & $\begin{array}{c}\text { Germany*** } \\
(0.00)\end{array}$ & Sweden (0.16) \\
\hline
\end{tabular}


Table 7 (continued)

\begin{tabular}{|c|c|c|c|c|}
\hline Country/[$\gamma]$ & $\Delta \mathrm{Y}$ & $\Delta \mathrm{SP}$ & $\Delta I$ & $\Delta \mathrm{HP}$ \\
\hline Sweden [1.20] & $\begin{array}{c}\text { Denmark** } \\
(0.01)\end{array}$ & $\begin{array}{l}\text { N. Zealand* } \\
\quad(0.09)\end{array}$ & Korea $(0.14)$ & Korea (0.22) \\
\hline $\begin{array}{c}\text { Switzerland } \\
{[1.05]}\end{array}$ & $\begin{array}{l}\text { Switzerland* } \\
\quad(0.09)\end{array}$ & $\begin{array}{l}\text { Switzerland } \\
(0.16)\end{array}$ & Japan (0.10) & $\begin{array}{l}\text { Switzerland } \\
\quad(0.24)\end{array}$ \\
\hline UK [2.15] & Korea* $^{*}(0.07)$ & Korea $(0.15)$ & Denmark* $(0.06)$ & N. Zealand (0.24) \\
\hline USA [2.29] & Japan* $(0.07)$ & Japan (0.14) & $\mathrm{UK}^{* * *}(0.00)$ & Japan (0.19) \\
\hline
\end{tabular}

(1) In the first column, if the estimated smooth parameter, $\gamma$, seen in the bracket, takes values higher (lower) than two, it suggests a strong (weak) transition based on the modelling specifications. Bold characters show strong transition countries $(\boldsymbol{\gamma} \geq 2)$. We attempt to classify rest of the countries as displaying semi-strong transition ( $1.86 \geq \boldsymbol{\gamma} \geq 1.65$ ) and weak transition $(1.65 \geq \boldsymbol{\gamma} \geq 1)$ (see Evidence Set 5 for a detail explanation). (2) Countries are arranged in descending order based on the magnitude of transition speeds in the columns of $2 / 3 / 4 / 5$. For instance, based on the income variable, Greece is the top country while based on the stock price Finland is the top country. Japan shows low transition speeds based on income, stock price and house price. (3) The figures in the parenthesis in the columns of 2/3/4/5 show the F-test (Chow test) on equality of the coefficients across regimes

$\mathrm{Y}$, income; SP, stock price; I, interest rates; HP, house price

$*, * *, * * *$ indicate that statistics are significant at the $10 \%, 5 \%$, and $1 \%$ level of significance, respectively

\section{Appendix 3}

\section{See Table 8.}


Table 8 Classification of countries according to multiple criteria

\begin{tabular}{|c|c|c|c|c|c|c|c|}
\hline \multirow{2}{*}{$\begin{array}{l}\text { Country name, } \\
\text { size, and economic } \\
\text { memberships } \\
\text { development }\end{array}$} & \multicolumn{2}{|c|}{$\begin{array}{l}\text { Bank- vs. } \\
\text { market-based } \\
\text { countries }^{a}\end{array}$} & \multicolumn{2}{|c|}{ Income level (WB) ${ }^{b}$} & \multicolumn{2}{|c|}{ Financial development ${ }^{\mathrm{c}}$} & \multirow{2}{*}{$\begin{array}{l}\text { Housing } \\
\text { ownership } \\
\text { ratio and } \\
\text { ownership } \\
\text { trends }\end{array}$} \\
\hline & BB & $\mathrm{MB}$ & $\begin{array}{l}\mathrm{HI}(\mathrm{WB}) \\
\& \mathrm{DC} \\
(\mathrm{UN})\end{array}$ & $\begin{array}{l}\mathrm{UM}(\mathrm{WB}) \\
\& \mathrm{DE}(\mathrm{UN}) \\
\& \mathrm{ET}(\mathrm{UN})\end{array}$ & Advanced & High & \\
\hline Australia (BOAX) & & + & $+_{(\mathrm{HI} \& \mathrm{DC})}$ & & (2) & & $(65 \%) \downarrow$ \\
\hline Austria (SEOA) & + & & ${ }_{(\mathrm{HI} \& \mathrm{DC})}$ & & (19) & & $(55 \%) \downarrow$ \\
\hline Belgium $^{\mathrm{d}}$ (SEOA) & + & & $+{ }_{(\mathrm{HI} \& D C)}$ & & (20) & & $(71 \%) \downarrow$ \\
\hline Canada (BOAX) & & + & $+_{(\mathrm{HI} \& \mathrm{DC})}$ & & (7) & & $(67 \%) \downarrow$ \\
\hline Denmark $(\mathrm{SEOA})^{\mathrm{e}}$ & + & & $+_{(\mathrm{HI} \& \mathrm{DC})}$ & & (15) & & $(62 \%) \downarrow$ \\
\hline Finland (SEA) & + & & $+_{(\mathrm{HI} \& \mathrm{DC})}$ & & & (23) & $(72 \%) \downarrow$ \\
\hline France (BEOA) & + & & $+_{(\mathrm{HI} \& \mathrm{DC})}$ & & (11) & & $(65 \%) \downarrow$ \\
\hline Germany (BEOA) & + & & $+_{(\mathrm{HI} \& \mathrm{DC})}$ & & (14) & & $(52 \%) \downarrow$ \\
\hline Greece (SEOA) & + & & $+_{(\mathrm{HI} \& D C)}$ & & & $(31)$ & $(74 \%) \downarrow$ \\
\hline Ireland (SOA) & & + & $+_{(\mathrm{HI} \& \mathrm{DC})}$ & & (17) & & $(70 \%) \downarrow$ \\
\hline Israel $(\mathrm{SOA})^{\mathrm{f}}$ & + & & + & $+(\mathrm{DE})$ & & (30) & $(68 \%) \downarrow$ \\
\hline Italy (BEOA) & + & & $+_{(\mathrm{HI} \& \mathrm{DC})}$ & & (10) & & $(72 \%) \downarrow$ \\
\hline Japan (BOA) & + & & ${ }_{(H I \& D C)}$ & & (8) & & $(65 \%) \uparrow$ \\
\hline Korea $(\mathrm{BOA})^{\mathrm{g}}$ & & + & + & $+(\mathrm{DE})$ & (6) & & $(57 \%) \uparrow$ \\
\hline $\begin{array}{l}\text { Netherlands } \\
\text { (BEOA) }\end{array}$ & & + & $+(\mathrm{I} \& \mathrm{DC})$ & & (18) & & $(69 \%) \uparrow$ \\
\hline $\begin{array}{l}\text { New Zealand } \\
\qquad(\mathrm{SOAX})^{\mathrm{h}}\end{array}$ & & + & ${ }_{\text {HI\&DC) }}^{+}$ & & & (29) & $(65 \%) \downarrow$ \\
\hline Norway (SOA) & + & & $+_{(H I \& D C)}$ & & & $(22)$ & $(83 \%) \downarrow$ \\
\hline Portugal (SEOA) & + & & ${ }^{+}(\mathrm{HI} \& D C)$ & & & (24) & $(75 \%) \downarrow$ \\
\hline
\end{tabular}


Table 8 (continued)

\begin{tabular}{|c|c|c|c|c|c|c|c|}
\hline \multirow{2}{*}{$\begin{array}{l}\text { Country name, } \\
\text { size, and economic } \\
\text { memberships } \\
\text { development }\end{array}$} & \multicolumn{2}{|c|}{$\begin{array}{l}\text { Bank- vs. } \\
\text { market-based } \\
\text { countries }^{\mathrm{a}}\end{array}$} & \multicolumn{2}{|c|}{ Income level $(\mathrm{WB})^{\mathrm{b}}$} & \multicolumn{2}{|c|}{ Financial development $^{\mathrm{c}}$} & \multirow{2}{*}{$\begin{array}{l}\text { Housing } \\
\text { ownership } \\
\text { ratio and } \\
\text { ownership } \\
\text { trends }\end{array}$} \\
\hline & $\mathrm{BB}$ & MB & $\begin{array}{l}\mathrm{HI}(\mathrm{WB}) \\
\& \mathrm{DC} \\
(\mathrm{UN})\end{array}$ & $\begin{array}{l}\mathrm{UM}(\mathrm{WB}) \\
\& \mathrm{DE}(\mathrm{UN}) \\
\& \mathrm{ET}(\mathrm{UN})\end{array}$ & Advanced & High & \\
\hline Russia $(B M)^{\mathrm{i}}$ & + & & & $+{ }_{(\mathrm{UM} \& \mathrm{ET})}$ & & $(32)$ & $(84 \%) \downarrow$ \\
\hline South Africa $(\mathrm{SM})^{\mathrm{j}}$ & & + & & ${ }^{+}(\mathrm{UM} \& \mathrm{DE})$ & & $(28)$ & $\mathrm{n} / \mathrm{a}$ \\
\hline Spain (BEOA) & + & & ${ }_{(H I \& D}$ & & $(5)$ & & $(78 \%) \downarrow$ \\
\hline Sweden (SEOA) & & + & ${ }_{(H I \& D}$ & & (13) & & $(65 \%) \downarrow$ \\
\hline Switzerland (SOA) & & + & ${ }_{(H I \& D}$ & & (1) & & $(51 \%) \uparrow$ \\
\hline USA (BOAX) & & + & ${ }_{(H I \& D}$ & & (4) & & $(64 \%) \downarrow$ \\
\hline
\end{tabular}


Table 8 (continued)

\begin{tabular}{|c|c|c|c|c|c|c|c|}
\hline \multirow{2}{*}{$\begin{array}{l}\text { Country name, } \\
\text { size, and economic } \\
\text { memberships } \\
\text { development }\end{array}$} & \multicolumn{2}{|c|}{$\begin{array}{l}\text { Bank- vs. } \\
\text { market-based } \\
\text { countries }^{\mathrm{a}}\end{array}$} & \multicolumn{2}{|c|}{ Income level (WB) ${ }^{b}$} & \multicolumn{2}{|c|}{ Financial development ${ }^{\mathrm{c}}$} & \multirow{2}{*}{$\begin{array}{l}\text { Housing } \\
\text { ownership } \\
\text { ratio and } \\
\text { ownership } \\
\text { trends }\end{array}$} \\
\hline & BB & MB & $\begin{array}{l}\mathrm{HI}(\mathrm{WB}) \\
\& \mathrm{DC} \\
(\mathrm{UN})\end{array}$ & $\begin{array}{l}\mathrm{UM}(\mathrm{WB}) \\
\& \mathrm{DE}(\mathrm{UN}) \\
\& \mathrm{ET}(\mathrm{UN})\end{array}$ & Advanced & High & \\
\hline UK (BEOAX) & & + & ${ }_{(\mathrm{HI} \& \mathrm{D}}$ & & (3) & & $(63 \%) \downarrow$ \\
\hline
\end{tabular}

In the first column; A: advanced economy; B: big country; S: small country; E: EU member; M: emerging economy; O: OECD member; X: Anglo-Saxon country. In the second column; BB: bank-based economy; MB: market-based economy. In the third column; HI: high-income country (WB); UM: upper-middle-income country (WB); DC: developed country (UN; 2018); DE: developing country (UN 2018); ET: economies in transition; WB: World Bank (2018). In the last column: ownership ratio $\downarrow / \uparrow$ : declining or increasing housing ownership ratio. n/a: Not available. Notes: (1) To define whether a country shows ownership or rental housing market characteristics, we use EuroStat (2019) [Internet: http://appsso. eurostat.ec.europa.eu/nui/show.do?dataset=ilc_lvho02\&lang=en (accessed on: 12 July, 2019).], EMF (2011), US Census Bureau [Internet: https://www.census.gov/housing/hvs/data/q119ind.html (accessed on: 12 July, 2019).], World Atlas [Internet: https://www.worldatlas.com/articles/countries-with-the-highest-home-ownership-rates.Htm 1 (accessed on: 12 July, 2019).] (for Canada and Russia), Trading Economics [Internet: https://tradingeconomics.com/south-korea/homeownership-rate (accessed on: 12 July, 2019).] (for Korea and Australia-2016- and New Zealand -2013-), Global Property Guide [Internet: https://www.globalpropertyguide.com/Middle-East/Israel/Price-History (accessed on: 12 July, 2019).] (for Israel for 2017) and Goodman and Mayer (2018) (for Japan, Switzerland for 2015) data for the observation period. (2) To define either a country is big or small, we utilize both GDP classification of IMF and WB. (3) In the column of financial development, the figure in the parantheses shows the ranking of the country in the Financial Development Index as of 2013 (see Svirydzenka 2016). If a country's ranking is equal or lower than 20 in this index, we arbitrarily classify it as the advanced financial development. Otherwise, we label as high financial development

${ }^{a}$ See, Borio (1996), Demirgüç-Kunt and Levine (1999), Levine (2002), Beck and Levine (2002), and Ludwig and Sløk (2004)

bSee, Nielsen (2013); WB (2018a)

${ }^{\mathrm{c}}$ We use Svirydzenka (2016) for the 2013 Country Rankings on Financial Development. Also see Cihak et al. (2012) and World Bank (2018b)

${ }^{\mathrm{d}}$ Demirgüç-Kunt and Levine (1999) indicate that relative activity measure of financial structure identifies Austria, Portugal, Belgium, Italy, and Finland as bank based

${ }^{\mathrm{e}}$ While Demirgüç-Kunt and Levine (1999) suggest that Denmark has a market-based financial system, Ludwig and Sløk (2004) and Beck and Levine (2002) indicate that Denmark has a bank-based financial system

${ }^{\mathrm{f}} \mathrm{UN}$ (2018) classifies Israel as a developing economy and high-income country according to per capita GNI (gross national income) in June 2017. WB suggests that Israel is a high-income country

g UN (2018) classifies Korea as a developing economy and high-income country according to per capita GNI in June 2017. World Bank (2018a) suggests that Korea is a high-income country

${ }^{\mathrm{h}}$ Demirgüç-Kunt and Levine (1999) indicate that New Zealand has a bank-based system. Beck and Levine (2002) suggest that New Zealand is classified as having unbalanced market-based system. As the Anglo-Saxon country, we classify New Zealand as the market-based country

${ }^{\mathrm{i}} \mathrm{UN}$ (2018) classifies Russian Federation as the economy in transition and upper middle income according to per capita GNI in June 2017. World Bank (2018a) classifies Russia as the upper-middle-income country. For the classification of Russia as the bank-based economy, we use Cihak et al. (2012) and World Bank (2018b)

jDemirgüç-Kunt and Levine (1999) indicate that their bank vs capitalization measure identifies South Africa as marketbased but also discuss that South Africa is also classified as intermediary-based rather than market-based system. Levine (2002) suggests that the size measure indicates that South Africa is very market-based. UN (2018) suggests that South Africa is a developing economy and also upper-middle-income country according to per capita GNI in June 2017. World Bank (2018a) suggests that South Africa is the upper-middle-income country 


\section{References}

Adämmer P (2019) lpirfs: An r package to estimate impulse response functions by local projections. The R J 11(2):421-438. https://doi.org/10.32614/RJ-2019-052

Akaike H (1974) A new look at the statistical model identification. IEEE Trans Autom Control 19:716-723

Albacete N, Lindner P (2017) How strong is the wealth channel of monetary policy transmission? A microeconometric evaluation for Austria. Monet Policy Econ 2017:32-53

Alp E, Seven Ü (2019) The dynamics of household final consumption: the role of wealth channel. Cent Bank Rev. https://doi.org/10.1016/j.cbrev.2019.03.002

Ando A, Modigliani F (1963) The life cycle hypothesis of saving: aggregate implications and tests. Am Econ Rev 53:55-84

Apergis N, Miller SM (2006) Consumption asymmetry and the stock market: empirical evidence. Econ Lett 93:337-342

Auclert A (2019) Monetary policy and the redistribution channel. Am Econ Rev 109(6):2333-2367. https:// doi.org/10.1257/aer.20160137

Auerbach AJ, Gorodnichenko Y (2012) Measuring the output responses to fiscal policy. Am Econ J Econ Pol 4(2):1-27

Auerbach AJ, Gorodnichenko Y (2013) Output spillovers from fiscal policy. Am Econ Rev 103(3):141-146

Backus, D. K., \& Kehoe, P. J. (1992). International evidence on the historical properties of business cycles. The American Economic Review, 864-888.

Barnichon R, Brownlees C (2019) Impulse response estimation by smooth local projections. Rev Econ Stat 101(3):522-530

Beck T, Levine R (2002) Industry growth and capital allocation: does having a market-or bank-based system matter? J Financ Econ 64(2):147-180

Benjamin JD, Chinloy P, Donald GJ (2004) Real estate versus financial wealth in consumption. J Real Estate Finance Econ 29:341-354

Berger D, Vavra J (2015) Consumption dynamics during recessions. Econometrica 83(1):101-154. https:// doi.org/10.3982/ecta11254

Berger D, Guerrieri V, Lorenzoni G, Vavra J (2017) House prices and consumer spending. Rev Econ Stud 85(3):1502-1542

Boone L, Girouard N, Wanner I (2002) Financial market liberalisation, wealth and consumption. OECD

Borio CEV (1996) Credit characteristics and the monetary policy transmission mechanism in fourteen industrial countries: facts, conjectures and some econometric evidence. In: Koos A (ed) Monetary policy in a converging Europe. Kluwer Academic Publishers, Norwell

Boskin MJ (1978) Taxation, saving and the rate of interest. J Polit Econ 86(2):3-27

Bostic R, Gabriel S, Painter G (2009) Housing wealth, financial wealth, and consumption: new evidence from micro data. Reg Sci Urban Econ 39(1):79-89

Brock W, Dechert W, Scheinkman J (1996) A test for independence based on the correlation dimension. Econ Rev 15(1):197-235

Brock W, Dechert W, Scheinkman J (1987) Test for independence based on the correlation dimension. Mimeo

Bunn P, Le Roux J, Reinold K, Surico P (2018) The consumption response to positive and negative income shocks. J Monet Econ 96:1-15

Campbell JY, Mankiw NG (1989) Consumption, income, and interest rates: reinterpreting the time series evidence. NBER Macroecon Annu 4:185-216

Carroll CD, Kimball MS (1996) On the concavity of the consumption function. Econometrica 64(4):981-992. https://doi.org/10.2307/2171853

Case KE, Quigley JM (2008) How housing booms unwind: income effects, wealth effects, and feedbacks through financial markets. Eur J Housing Policy 8(2):161-180

Case KE, Quigley JM, Shiller RJ (2005) Comparing wealth effects: the stock market versus the housing market. Adv Macroecon 5(1):1-32

Case KE, Quigley JM, Shiller RJ (2013) Wealth effects revisited 1975-2012. Crit Finance Rev 2:101-128

Case KE, Quigley JM, Shiller RJ (2001) Comparing wealth effects: the stock market versus the housing market. National Bureau of Economic Research Working Paper No. 8606. NBER, Cambridge

Case KE, Quigley JM, Shiller RJ (2011) Wealth effects revisited 1978-2009 (No. w16848). National Bureau of Economic Research 
Catte P, Girouard N, Price RW, André C (2004) Housing markets, wealth and the business cycle. Working Paper No. ECO/WKP(2004)17. OECD

Christelis D, Georgarakos D, Jappelli T, Pistaferri L, van Rooij M (2019) Asymmetric consumption effects of transitory income shocks. Econ J 129(622):2322-2341. https://doi.org/10.1093/ej/uez013

Čihák M, Demirgüç-Kunt A, Feyen E, Levine R (2012) Benchmarking financial systems around the world. World Bank policy research working paper (6175)

Coşkun Y, Atasoy BS, Morri G, Alp E (2018) Wealth effect and household final consumption: stock and housing market channels. Int J Financ Stud. https://doi.org/10.3390/ijfs6020057

Coskun EA, Apergis N, Coskun Y (2020) Threshold effects of housing affordability and financial development on the house p rice-consumption nexus. Int J Financ Econ. https://doi.org/10.1002/ijfe.2242

D'Orlando F, Sanfilippo E (2010) Behavioral foundations for the Keynesian consumption function. J Econ Psychol 31(6):1035-1046. https://doi.org/10.1016/j.joep.2010.09.004

De Jong RM, Sakarya N (2016) The econometrics of the Hodrick-Prescott filter. Rev Econ Stat 98(2):310-317

Del Negro M, Giannone D, Giannoni MP, Tambalotti A (2019) Global trends in interest rates. J Int Econ 118:248-262

Demirgüç-Kunt A, Levine R (1999) Bank-based and market-based financial systems: cross-country comparisons. Policy Working Paper No. 2143. World Bank, Washington, DC

Donihue M, Avramenko A (2007) Decomposing consumer wealth effects: evidence on the role of real estate assets following the wealth cycle of 1990-2002. BE J Macroecon 7:1. https://doi.org/10.2202/19351690.1472

Duesenberry JS (1949) Income, saving, and the theory of consumer behavior

Dvornak N, Kohler M (2003) Housing wealth, stock market wealth and consumption: a panel analysis for Australia. Research discussion paper, No. 2003- 07. Economic Research Department, Reserve Bank of Australia, Sydney

Eggertsson GB, Juelsrud RE, Wold EG (2017) Are negative nominal interest rates expansionary? (No. w24039). National Bureau of Economic Research

Elliot JW (1980) Wealth and wealth proxies in a permanent income model. Quart J Econ 95:509-535

EMF (European Mortgage Federation) (2011) HYPOSTAT 2016: a review of Europe's mortgage and housing markets

Fisher I (1930) Theory of interest: as determined by impatience to spend income and opportunity to invest it. Augustusm Kelly Publishers, Clifton

Friedman M (1957) The permanent income hypothesis. In: A theory of the consumption function. Princeton University Press, pp 20-37

Gali J (1994) Keeping up with the Joneses: consumption externalities, portfolio choice, and asset prices. J Money Credit Bank 26(1):1-8

Genesove D, Mayer C (2001) Loss aversion and seller behavior: evidence from the housing market. Q J Econ 116(4):1233-1260

González-Rivera G (1998) Smooth-transition GARCH models. Stud Nonlinear Dyn Econ 3:2

Goodman LS, Mayer C (2018) Homeownership and the American dream. J Econ Perspect 32(1):31-58

Gourinchas PO, Rey H (2018) Global real rates: a secular approach. BIS Working Papers No 793

Granger C, Teräsvirta T (1993) Modelling nonlinear economic relationships. Oxford University Press, Oxford

Groenewold N (2003) Consumption and stock prices: can we distinguish signalling from wealth effects? Department of Economics, University of Western Australia

Gylfason T (1981) Interest rates, inflation, and the aggregate consumption function. Rev Econ Stat 233-245

Hamilton JD (2018) Why you should never use the Hodrick-Prescott filter. Rev Econ Stat 100(5):831-843

Hansen HJ (1996) The impact of interest rates on private consumption in Germany. Discussion Paper 3/96. Deutsche Bundesbank, Frankfurt

Harvey A, Trimbur T (2008) Trend estimation and the Hodrick-Prescott filter. J Jpn Stat Soc 38(1):41-49

Hodrick RJ, Prescott EC (1997) Postwar US business cycles: an empirical investigation. J Money Credit Bank 1-16

Husby RD (1983) The nonlinear consumption function: could Reagen be right?/993. BEBR faculty working paper; no. 993

Hviid SJ, Kuchler A (2017) Consumption and savings in a low interest-rate environment (No. 116). Danmarks Nationalbank Working Papers 
Iacoviello M (2004) Consumption, house prices, and collateral constraints: a structural econometric analysis. J Hous Econ 13(4):304-320

Jawadi F, Léoni P (2012) Nonlinearity, cyclicity and persistence in consumption and income relationships: research in honor of Melvin. J Hinich Macroecon Dyn 16(S3):376-393

Jawadi F, Sousa RM (2014) The relationship between consumption and wealth: a quantile regression approach. Revue D’économie Politique 124(4):639-652

Jawadi F, Soparnot R, Sousa RM (2017) Assessing financial and housing wealth effects through the lens of a nonlinear framework. Res Int Bus Financ 39:840-850

Jordà Ò (2005) Estimation and inference of impulse responses by local projections. Am Econ Rev 95(1):161-182

Jordà Ò, Taylor AM (2016) The time for austerity: estimating the average treatment effect of fiscal policy. Econ J 126(590):219-255

Jordà Ò, Schularick M, Taylor AM (2015) Betting the house. J Int Econ 96:S2-S18

Jordà Ò, Schularick M, Taylor AM (2020) The effects of quasi-random monetary experiments. J Monet Econ 112:22-40

Kapoor M, Shamika R (2009) The effect of interest rate on household consumption: evidence from a natural experiment in India. February 20. Available online: https://ssrn.com/abstract=1346813. Accessed 1 Feb 2021

Katrakilidis C, Trachanas E (2012) What drives housing price dynamics in Greece: new evidence from asymmetric ARDL cointegration. Econ Model 29(4):1064-1069

Keynes JM (1936) The general theory of employment, interest and money. Macmillan, London

Kilian L, Kim YJ (2011) How reliable are local projection estimators of impulse responses? Rev Econ Stat 93(4):1460-1466

Kydland FE, Prescott EC (1990) Business cycles: real facts and a monetary myth. Fed Reserve Bank Minneap Q Rev 14(2):3-18

Leibenstein H (1950) Bandwagon, snob, and Veblen effects in the theory of consumers' demand. Q J Econ 64(2):183-207

Lettau M, Ludvigson SC (2004) Understanding trend and cycle in asset values: reevaluating the wealth effect on consumption. Am Econ Rev 94(1):276-299

Lettau M, Ludvigson S, Steindel C (2002) Monetary policy transmission through the consumption-wealth channel. FRBNY Econ Policy Rev 5:117-133

Levine R (2002) Bank-based or market-based financial systems: which is better? J Financ Intermed $11: 398-428$

Li W, Yao R (2007) The life-cycle effects of house price changes. J Money Credit Bank 39(6):1375-1409

Ljung GM, Box GEP (1978) On a measure of lack of fit in time-series models. Biometrika 65:297-303

Ludvigson S, Steindel C, Lettau M (2002) Monetary policy transmission through the consumption-wealth channel. In: Economic policy review. Federal Reserve Bank of New York, pp 117-33

Ludwig A, Sløk T (2004) The relationship between stock prices, house prices and consumption in OECD countries. Top Macroecon 4:1-24

Luukkonen R, Saikkonen P, Teräsvirta T (1988) Testing linearity against smooth transition autoregressive models. Biometrika 75:491-499

MacDonald G, Mullineux A, Sensarma R (2011) Asymmetric effects of interest rate changes: the role of the consumption-wealth channel. Appl Econ 43(16):1991-2001. https://doi.org/10.1080/ 00036840902950572

McMillan DG (2001) Nonlinear predictability of stock market returns: evidence from nonparametric and threshold models. Int Rev Econ Financ 10:353-368

Mignon V, Dufrénot G (2004) Modelling the French consumption function using SETAR models. Econ Bull 3(20):1-16

Mishkin FS (1976) Illiquidity, consumer durable ex-penditure, and monetary policy. Am Econ Rev 66:642-654

Mishkin F (2007) Housing and the monetary transmission mechanism. Working Paper, Finance and Economic Discussion Series. Federal Reserve Board, Washington, DC

Nadeau R, Cloutier E, Guay JH (1993) New evidence about the existence of a bandwagon effect in the opinion formation process. Int Polit Sci Rev 14(2):203-213

Nielsen L (2013) How to classify countries based on their level of development? Soc Indic Res 114(3):1087-1107 
Palley TI (2010) The relative permanent income theory of consumption: a synthetic Keynes-Duesenberry-Friedman model. Rev Polit Econ 22(1):41-56. https://doi.org/10.1080/09538250903391954

Patterson KD (1993) The impact of credit constraints, interest rates and housing equity withdrawal on the intertemporal pattern of consumption — a diagrammatic analysis. Scottish J Polit Econ 40:391-407

Peltonen TA, Sousa EM, Vansteenkiste IS (2012) Wealth effects in emerging market economies. Int Rev Econ Financ 24:155-166

Poterba JM, Samwick AA, Shleifer A, Shiller RJ (1995) Stock ownership patterns, stock market fluctuations, and consumption. Brook Pap Econ Act 1995(2):295-372

Ravn MO, Uhlig H (2002) On adjusting the Hodrick-Prescott filter for the frequency of observations. Rev Econ Stat 84(2):371-376

Romer CD (1990) The great crash and the onset of the great depression. Q J Econ 105(3):597-624

Schooley DK, Worden DD (2008) A behavioral life-cycle approach to understanding the wealth effect. Bus Econ 43(2):7-15

Schwarz G (1978) Estimating the dimension of a model. Ann Stat 6:461-464

Shefrin HM, Thaler R (1988) The behavioral lifecycle hypothesis. Econ Inq 26(4):169-177

Shirvani H, Wilbratte B (2000) Does consumption respond more strongly to stock market declines than to increases? Int Econ J 14:41-49

Simo-Kengne BD, Gupta R, Bittencourt M (2013) The impact of house prices on consumption in South Africa: evidence from provincial-level panel VARs. Hous Stud 28:1133-1154

Siokis FM (2005) Policy transmission and the consumption-wealth channel. Appl Financ Econ Lett $1: 349-353$

Slacalek J (2009) What drives personal consumption? The role of housing and financial wealth. BE J Macroecon 9:1

Sousa, R. M. (2005). Consumption, (Dis)Aggregate Wealth and Asset Returns. January. NIPE Working Paper No. 09-2005.

Springer WL (1975) Did the 1968 Surcharge Really Work? Am Econ Rev 65:644-659

Starr-McCluer M (2002) Stock market wealth and consumer spending. Econ Inq 40(1):69-79

Svirydzenka K (2016) Introducing a new broad-based index of financial development. International Monetary Fund

Teräsvirta T (1994) Specification, estimation, and evaluation of smooth transition autoregressive models. J Am Stat Assoc 89:208-218

Teräsvirta T, Anderson HM (1992) Characterizing nonlinearities in business cycles using smooth transition autoregressive models. J Appl Econ 7:119-136

Thaler RH (1990) Saving, fungibility and mental accounts. J Econ Perspect 4:193-205

Thaler R (1994) Psychology and saving policies. Am Econ Rev 84(2):186-192

Tsai IC, Lee CF, Chiang MC (2011) The asymmetric wealth effect in the us housing and stock markets: evidence from the threshold cointegration model. J Real Estate Finance Econ 45:1005-1020

UN (2018). World Economic Situation and Prospects 2018. New York, the US.

Veblen T (1899) The theory of Leisure class. Dover Publications, New York

World Bank (2018a) World Bank list of economies (June 2018). Internet: https://www.ed.ac.uk/files/atoms/ files/world_bank_country_classifications_2018.pdf. Accessed 22 June 2019

World Bank (2018b) Global Financial Development Report 2017/2018.Internet: https:/openknowledge. worldbank.org/bitstream/handle/10986/28482/9781464811487.pdf. Accessed 22 June 2019

Wright C (1967) Some evidence on the interest elasticity of consumption. Am Econ Rev 57:850-854

Publisher's Note Springer Nature remains neutral with regard to jurisdictional claims in published maps and institutional affiliations. 